\title{
Co-culturing of native bacteria from drinking water treatment plant with known degraders to accelerate microcystin removal
}

\author{
Pratik Kumar ${ }^{\mathrm{a}}$, Krishnamoorthy Hegde ${ }^{\mathrm{a}}$, Satinder Kaur Brar ${ }^{\mathrm{a}, \mathrm{b}, *}$, Maximiliano Cledon ${ }^{\mathrm{c}}$, \\ Azadeh Kermanshahi-pour ${ }^{\mathrm{d}}$, Audrey Roy-Lachapelle ${ }^{\mathrm{e}, \mathrm{f}}$, Sébastien Sauvé ${ }^{\mathrm{e}}$, Rosa Galvez-Cloutier ${ }^{\mathrm{g}}$ \\ a INRS-ETE, Université du Québec, 490, Rue de la Couronne, Québec G1K 9A9, Canada \\ b Department of Civil Engineering, Lassonde School of Engineering, York University, North York, Toronto M3J 1P3, Ontario, Canada \\ c CIMAS (CONICET, UnComa, Rio Negro), Güemes 1030, San Antonio Oeste, Rio Negro, Argentina \\ d Biorefining and Remediation Laboratory, Department of Process Engineering and Applied Science, Dalhousie University, 1360 Barrington Street, Halifax, Nova Scotia B3J 1Z1, Canada \\ e Department of Chemistry, Université de Montréal, Montréal, QC, Canada \\ ${ }^{\mathrm{f}}$ Environment and Climate Change Canada, 105 rue McGill, H2Y $2 E 7$ Montréal, QC, Canada \\ $\mathrm{g}^{\mathrm{F}}$ Faculté des Sciences et Génie, Département de génie civil et génie des Eaux, Université Laval, Québec, Québec, Canada
}

\section{A R T I C L E I N F O}

\section{Keywords}

Biofilter

Co-culture

Microcystin

Water quality

Drinking water

Sand filter

\begin{abstract}
A B S T R A C T
The biofilm-mediated bioremediation of drinking water source for Microcystin-LR degradation under various water quality parameters was investigated using sand filter with known Microcystin (MC)-degrading bacterial genera: Arthrobacter (A), Bacillus (B) and Sphingomonas (S), both under individual (A, B and S) as well as co-culture condition $(\mathrm{A}+\mathrm{X}, \mathrm{B}+\mathrm{X}$ and $\mathrm{S}+\mathrm{X}$ ) with the native bacterial strains (Pseudomonas fragi and Chryseobacterium $\mathrm{sp} .=\mathrm{X}$ ). These native bacterial strains were isolated from the filtration unit of a drinking water treatment plant (DWTP). Before starting the filter operation, the biofilm-forming ability of MC-degraders was evaluated using a unique experimental set-up. The study showed that the MC-LR removal was enhanced by $38 \%$ using S $+\mathrm{X}$ filter as compared to the uninoculated filter (control). Except for Bacillus sp., MC-degraders in the form of Arthrobacter ramosus and Sphingomonas sp. enhanced the MC removal potential of the native bacterial strains (X) by $10 \%$ and $17 \%$, respectively. The central composite design was used to obtain an optimized input parameter ( $\mathrm{pH}$, temperature, initial turbidity and retention time) for the filter operation. Various output parameters including dissolved organic carbon (DOC), total coliform, turbidity, dissolved oxygen, MC-LR toxicity and ammonia were analyzed to form a well-generalized model with a desirability index of 0.638 . Overall, filter $S+X$ achieved a non-detectable MCs concentration in some cycles and showed an average of $>30 \%$ DOC and $>80 \%$ of total coliform removal along with an under-regulated removal of nitrite, nitrate and ammonia. However, MC-LR breakthrough occurred after 8 weeks of filter operation. These studies demonstrated the effectiveness of inoculating MC-degraders in an existing filtration unit of a DWTP to remove the seasonal occurrence of MCs in the water source.
\end{abstract}

\section{Introduction}

Cyanotoxins are the secondary metabolites which are produced by cyanobacteria. Microcystin-LR is a cyanotoxin which is prominent in most cyanobloom-affected water bodies. Microcystins (MCs) are stable in the water bodies and sunlight alone is insufficient in their degradation as it also needs photosensitizers. Even the rate of photosensitized degradation was found to be rather low $\left(0.34 \times 10-3\left(\mathrm{~kJ} \mathrm{~m}^{-2}\right)^{-1}\right)$ where in-situ half-life for MC-LR was estimated to be around 90-120 days per meter depth of the water column [1]. WHO has set a preliminary guideline for MC-LR in drinking water as $1 \mu \mathrm{g} / \mathrm{L}$ [2].
Most of the Drinking Water Treatment Plants (DWTPs) procuring raw water from such sources, take little to no preventive measures to remove MC-LR. Microcystins are stable and recalcitrant during the conventional water treatment processes [3]. For example, during ozone treatment, the presence of natural organic matter (NOMs) reduces the dosed-ozone concentration (as ozone also degrades NOMs) and hence reduces the MCs removal efficiency [4]. In addition, conventional coagulation/flocculation treatment is partially effective as the long-term flocs stacking releases microcystin from Microcystis aeruginosa [5], and pre-chlorination creates a redistribution problem of toxins in free water solution [6]. On the other hand, the post-chlorination process

\footnotetext{
* Corresponding author at: INRS-ETE, Université du Québec, 490, Rue de la Couronne, Québec G1K 9A9, Canada.

E-mail address: Satinder.Brar@lassonde.yorku.ca (S.K. Brar)
} 
demands a high chlorine dose to cope up with the presence of high microcystin level in the filtered water $[7,8]$. Moreover, such chemical treatment processes may cause the formation of toxic or harmful metabolites, e.g.: disinfection by-products from chlorination $[9,10]$, whereas physical bioadsorption treatment, such as bio-sand filtration, not only promises effective removal of microcystin but also reduces the number of toxic by-products $[11,12]$.

Few studies have shown an effective removal of MCs through biosand filter while some studies have reported less efficiency and slow degradation rate [13-15]. Biofilters are becoming a more acceptable form of water treatment both under commercial scale (DWTPs) as well as for the smaller communities. They involve no electricity, requires less maintenance and no additional chemicals which otherwise could promote the production of toxic metabolites. Many bacterial strains isolated from water sources where the previous history of cyanotoxin presence was observed, showed successful MCs removal. Such bacteria were inoculated in a sand filter column to successfully study the MCs degradation $[16,17]$. Biological degradation of MC-LR using in-situ cultured bacteria has also been found to proceed with non-toxic by-products formation [18-20]. However, to the best of the authors knowledge, exploration of these known or unknown microcystin-degraders, co-cultured with the native bacterial strains isolated from a DWTP-sand filter has not been studied so far. Such co-culturing technique is hypothesized to further enhance the MC-LR removal.

In the present study, three different MC-LR-degraders of genera ${ }^{1}$ : Arthrobacter (A), Bacillus (B) and Sphingomonas (S) are individually co-cultured $(\mathrm{A}+\mathrm{X}, \mathrm{B}+\mathrm{X}$ and $\mathrm{S}+\mathrm{X})$ and inoculated with the combination of native bacterial strains $(\mathrm{X})$ to check for the MC-LR degradation using biosand filter. These MC-LR-degraders are also evaluated individually (A, B and S) to depict the MC-LR removal and the results are compared with the uninoculated filter $(C)$ and their co-cultured counterparts $(\mathrm{A}+\mathrm{X}, \mathrm{B}+\mathrm{X}$, and $\mathrm{S}+\mathrm{X})$. Following three hypotheses form the backbone of this research work:

1) The native bacterial strains (X) could be potent enough to carry out an effective MC-LR degradation.

2) The native bacterial strains need more assistance in the form of MC-LR degraders to carry out MC-LR removal.

3) The MC-LR-degraders can co-exist with the native bacterial population to enhance the degradation of MC-LR.

The most dominant native strains isolated from the collected biofilm sample of the sand filtration unit in DWTP, are identified as Chryseobacterium sp. and Pseudomonas fragi using NCBI BLAST service in our previous study [21]. They were identified using 16S rDNA and deposited in NCBI GenBank with Acc No. MH150821 and MH150822, respectively. From our previous study, they have also been identified as a good MC-LR degrader (overall 97\% and individually $>80 \%$ MC-LR degradation within ten days of incubation). Hence, throughout this study, filter $\mathrm{X}$ represents a "modified" model filter ${ }^{2}$ for DWTP filtration unit (Chemin Ste-Foy, Quebec City, Canada). This study also evaluates the performance of sand filtration in terms of various water quality parameters such as: turbidity, coliform, nitrate, nitrite, ammonia, total organic carbon, dissolved oxygen (DO), $\mathrm{pH}$, conductivity and MC-LR toxicity assay.

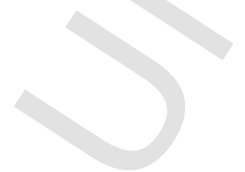

\footnotetext{
${ }^{1}$ Not all the species of the same genera are Microcystin-degraders

2 Sand media is grinded (as obtained from DWTP, hence the word modified), and the dominant microbial community was opted
}

\section{Material and methods}

\subsection{Chemicals and microorganisms}

Microcystin-LR was purchased from Cayman Chemicals (Ann Arbor, Michigan, MI, USA). 3-(4, 5-dimethylthiazol-2-yl)-2,5-diphenyltetrazolium bromide (MTT) was purchased from Sigma Aldrich, (Ontario, Canada) for the MTT assay.

Arthrobacter ramosus (NRRL B-3159), Bacillus sp. (NRRL B-14393), Sphingomonas sp. (NRRL B-59555), Rhizobium meliloti and Staphylococcus epidermidis were purchased from the NRRL Agricultural Research Service (ARS) culture collection. The last two strains were used as the bioindicator to measure the toxicity of the filtered effluent and as a positive control representing the biofilm forming strain, respectively. All the analytical reagents used in preparing nutrient and culture media were brought from Fisher Scientific, (Ontario, Canada).

\subsection{Screening of the bacterial strains}

Screening of the bacterial strains (three of them: A, B, and S) was performed to investigate their ability in forming biofilm over the sand media. Fig. 1 shows the schematic representation of the unique set-up prepared for this objective (laboratory set-up shown in Supplementary Fig. S1). A model reactor of plastic material consisting of 10-gram sand media was placed in replica for each inoculum source (Fig. 1 and Supplementary Fig. S1). After every 4-h, $20 \mathrm{~mL}$ (charge volume ${ }^{3}$ greater than the pore space) of inoculum $\left(6 \times 10^{7}\right.$ cells $\left./ \mathrm{mL}\right)$ was passed through the model reactors pre-set by the automatic dosage pump. The nutrient water of high chemical oxygen demand $(800 \mathrm{mg} / \mathrm{L})$ served as the matrix for the inoculum (to assist fast and active biofilm formation ${ }^{4}$ ). The operation was continued in a recirculation mode for 19 days to reach a conclusive evidence of mature biofilm formation. The assay results were compared with the negative control (without inoculated cells) and positive control (Staphylococcus epidermidis: known to be a good biofilm former) [22].

After every 3, 7, 11, 16 and 19 days, $^{5}$ a little portion of sand media (around $0.3 \mathrm{~g}$ ) was taken from the top layer and was suspended in $1.5 \mathrm{~mL}$ of tap water ${ }^{6}$ and vortexed (to draw out the attached bacterial cells and biomass into the solution). Post-vortex, the liquid portion was drawn in a $200 \mu \mathrm{L}$ volume to seed the wells of a 96-well plate (6 wells per sample). Biomass in three wells was stained using $100 \mu \mathrm{L}$ of $0.1 \%(\mathrm{w} / \mathrm{v})$ crystal violet (CV) and $100 \mu \mathrm{L}$ of MTT solution $(7 \mathrm{mg} /$ $10 \mathrm{~mL}$ ) was injected into the leftover three wells. Similarly, the process was carried out for the samples of other strains. Afterward, the plate was incubated overnight at $35 \pm 2{ }^{\circ} \mathrm{C}$ for crystal violet (CV) assay and $4 \mathrm{~h}$ at $35 \pm 2{ }^{\circ} \mathrm{C}$ for MTT assay. For CV assay, the wells were carefully washed with phosphate buffer solution ( $\mathrm{pH} 7.4)$ to remove any loosely attached biomass followed by the addition of $300 \mu \mathrm{L}$ dimethyl sulfoxide (DMSO) solution to solubilize the stained biomass. While for MTT assay, the formed precipitate (formazan: blue color) after drying was dissolved using $300 \mu \mathrm{L}$ of DMSO solution. Spectrophotometric reading ${ }^{7}$ was taken

\footnotetext{
${ }^{3}$ Charge volume is defined as the volume of inoculum passage in the model filter compared to its bulk capacity

${ }^{4}$ For the first five days COD: $800 \mathrm{mg} / \mathrm{L}$ was maintained, thereafter the COD was gradually decreased to $190 \mathrm{mg} / \mathrm{L}$ by the end of 12 days (quite close to Lake water COD). Hence nutrients were replenished each time COD was changed ( 2 days interval).

${ }^{5}$ First set of model filter was used exclusively for day 3 and day 7 sample, while 2nd set for day 11, day 16 and day 19 sample in order to avoid underestimation of biofilm quantification each time sample is being taken out.

${ }^{6}$ Tap water was chosen instead of milli-Q or distilled water to allow bioactivity of cells to be intact or otherwise bacterial cells can die due to shock (no conductivity in milli-Q water)

${ }^{7}$ For MTT assay: maximum absorbance was reported as $550.5 \mathrm{~nm}$ and for CV assay, it was $590.9 \mathrm{~nm}$ (as determined from the spectrum run)
} 


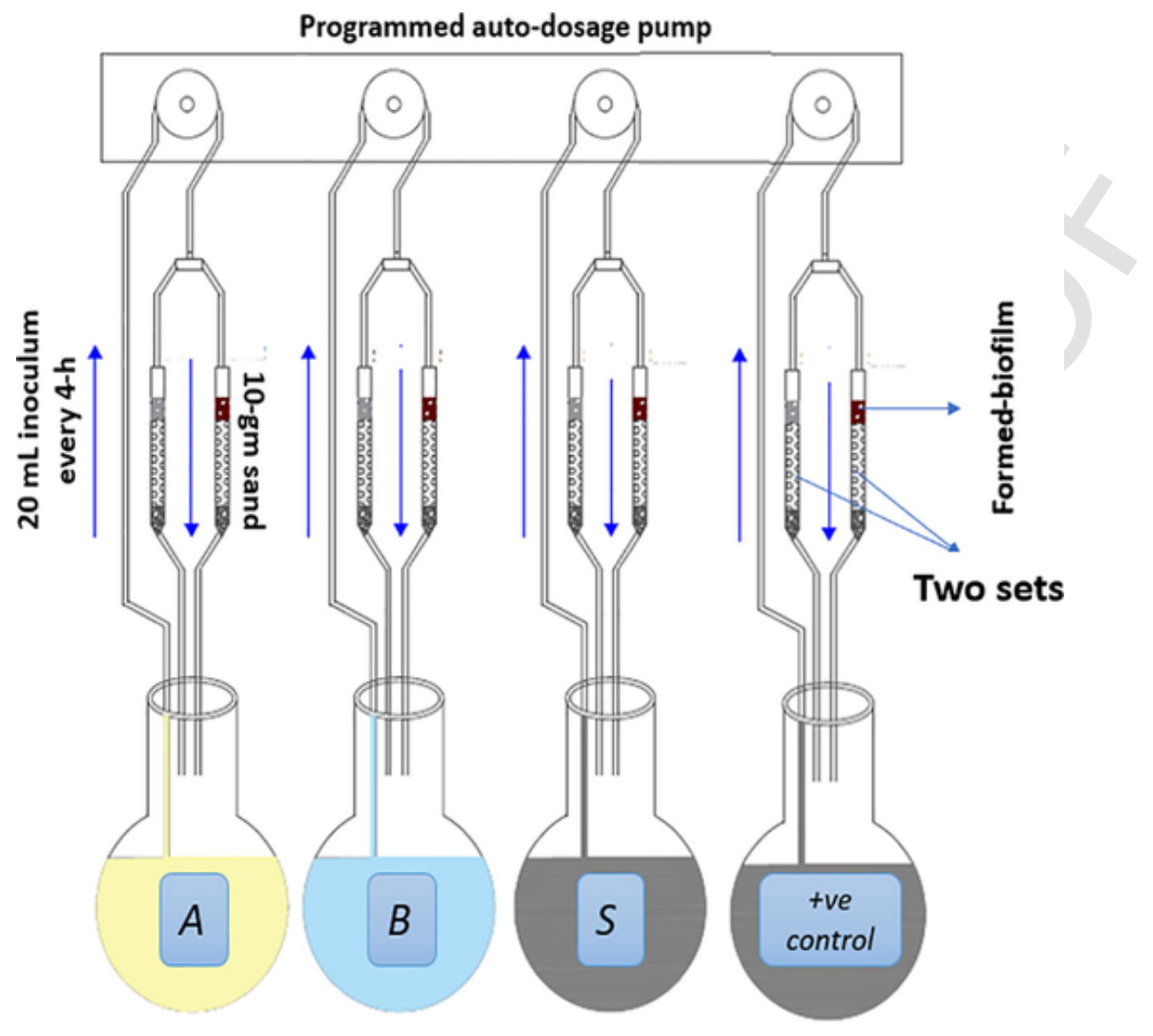

\section{A: Arthrobacter ramosus; B= Bacillus sp.; $\mathbf{S}=$ Sphingomonas $s p$.}

Fig. 1. Arrangement/set-up to study the screening of the biofilm-forming bacteria.

at $550 \mathrm{~nm}$ and $590 \mathrm{~nm}$ for MTT and CV assay, respectively, to quantify the cell viability (MTT assay) and cell biomass (CV assay). This experiment provided more information to assess the ability of the bacterial strain to form biofilm and not directly the biofilm formed on the sand grain.

\subsection{Optimization of input parameters using central composite design}

Before the onset of filter operation, optimization experiment was performed to understand the strength and best initial working conditions of sand filter media (for the physical parameters) comprising initial turbidity, $\mathrm{pH}$, critical standby period (retention time) of filter run and temperature. Three/four levels of inputs were designed for each parameter: $\mathrm{pH}$ of 6,7 , and 8; initial turbidity of $10 \mathrm{NTU}, 20$ NTU and $30 \mathrm{NTU}$; temperature of $10^{\circ} \mathrm{C}, 20^{\circ} \mathrm{C}$ and $30^{\circ} \mathrm{C}$, while critical standby period $\left(\mathrm{CSTI}^{8}\right)$ of $1 \mathrm{~h}, 2 \mathrm{~h}, 3 \mathrm{~h}$ and $4 \mathrm{~h}$. The lake water (Lake Sainte-Anne $(47.262879 \mathrm{~N},-71.665158 \mathrm{~W})$ was used as a solution matrix with suitable adjustments of turbidity (mimicking with turbid-hydrated clay suspension kept overnight), $\mathrm{pH}$ (hydrochloric acid/sodium hydroxide base) and temperature (heating ${ }^{9}$ ). Table 1 lists the details and necessary information derived from the optimization experiment. Based on the limited number of the glass columns available, the whole

${ }^{8}$ CSTI: It is defined as the minimum time period for which a filter should be run for a consecutive (or successive) operation without much affecting the output variables tested (to get more desirable filter operation).

$9^{9}$ For obtaining water at temperature $10^{\circ} \mathrm{C}, 20^{\circ} \mathrm{C}$ and $30^{\circ} \mathrm{C}$, the lake water stored in the cooling chamber was heated over the hot plate. optimization experiment was divided into two parts: a) 3-level of temperature and 3-level of $\mathrm{pH}$ ( 9 combinations); b) 3-level initial turbidity and 4-level critical time charge period (12 combinations). Hence, a total of 21 combinations of initial parameters were designed.

To optimize these initial conditions, the output parameters (analyzed for filtered samples) in the form of total coliform removal, turbidity removal, MC-LR assay (toxicity determination), dissolved oxygen-carbon removal (DOC), flow rate, change in $\mathrm{pH}$, dissolved oxygen, electrical conductivity were determined. The weighted importance for each output parameter was set according to the preference of the experimental objective. For instance, MC-LR assay, total coliform removal, DOC removal, and turbidity removal were set at high priority weights of 5,5 , 4 and 4, respectively (other parameters set to 2 or 3 based on importance). With the help of central composite design (Design-Expert 7.0) and weighted importance of all the output parameters, a definite and critical solution (in coded value), i.e., the optimized value of initial turbidity, temperature, $\mathrm{pH}$ and filter standby period was determined.

\subsection{Sand column experiment and filter maintenance}

After the screening test and the optimization experiment, the glass columns were installed in a top-down flow arrangement as shown in Fig. 2. Sand media was obtained from the filtration unit of the drinking water treatment plant (Chemin Ste-Foy, Quebec City, Canada). A total of eight glass columns (diameter: $25 \mathrm{~mm}$, thickness $2 \mathrm{~mm}$, height: $650 \mathrm{~mm}$ ) were installed, packed with the ground sand particles of effective diameter: $\mathrm{D}_{10}=180 \mu \mathrm{m}$ and coefficient of uniformity: $\mathrm{C}_{\mathrm{u}}=2.32$ for about $490 \mathrm{~mm}$ height. About $40 \mathrm{~mm}$ of drainage was provided 
Table 1

Optimization results compiled in the form of the model equations using central composite design.

\begin{tabular}{|c|c|c|c|c|c|c|}
\hline Output Parameter & Input Parameter $^{1}$ & $\begin{array}{l}\text { The } \\
\text { weight } \\
\text { assigned } \\
\text { to the } \\
\text { output } \\
\text { parameter } \\
\text { (out of 5) }\end{array}$ & Model Equation & $\begin{array}{l}\text { Significant/ No } \\
\text { significant }\end{array}$ & $\begin{array}{l}\text { Significant } \\
\text { input co- } \\
\text { efficient }\end{array}$ & $\begin{array}{l}\text { Output } \\
\text { value } \\
\text { based } \\
\text { on } \\
\text { desired } \\
\text { value } \\
(0.638)\end{array}$ \\
\hline \multirow[t]{2}{*}{ Turbidity removal } & $\begin{array}{l}\text { A1 }=\text { Turbidity; } \\
\text { B1 = Critical } \\
\text { Time }\end{array}$ & 4 & $77.70+4.35 \mathrm{~A} 1-0.83 \mathrm{~B} 1+0.29 \mathrm{~A} 1 \mathrm{~B} 1-3.72 \mathrm{~A} 1^{2}-3.54 \mathrm{~B} 1^{2}$ & SM & $\begin{array}{l}\mathrm{A} 1, \mathrm{~B} 1 \\
\mathrm{~A} 1^{2}, \mathrm{~B} 1^{2}\end{array}$ & 79.44 \\
\hline & $\begin{array}{l}\mathrm{A} 2=\mathrm{pH} \\
\mathrm{B} 2=\text { Temperature }\end{array}$ & 4 & $81.29+0.08 \mathrm{~A} 2-0.19 \mathrm{~B} 2+0.08 \mathrm{~A} 2 \mathrm{~B} 2+0.15 \mathrm{~A} 2^{2}+0.12 \mathrm{~B} 2^{2}$ & NSM & - & 80.64 \\
\hline \multirow[t]{2}{*}{ Coliform removal } & $\begin{array}{l}\text { A1 = Turbidity; } \\
\text { B1 = Critical } \\
\text { Time }\end{array}$ & 5 & $55.75+0.63 \mathrm{~A} 1-2.81 \mathrm{~B} 1-1.1 \mathrm{~A} 1 \mathrm{~B} 1-1.12 \mathrm{~A} 1^{2}$ & NSM & $\begin{array}{l}\mathrm{A} 1, \mathrm{~A} 1^{2}, \\
\mathrm{~A} 1 \mathrm{~B} 1\end{array}$ & 54.75 \\
\hline & $\begin{array}{l}\mathrm{A} 2=\mathrm{pH} \\
\mathrm{B} 2=\text { Temperature }\end{array}$ & 5 & $57.5+5.8 \mathrm{~A} 2=1.7 \mathrm{~B} 2-6.8 \mathrm{~A} 2 \mathrm{~B} 2-9.8 \mathrm{~A} 2^{2}+2.6 \mathrm{~B} 2^{2}$ & NSM & - & 59.55 \\
\hline \multirow[t]{2}{*}{ DOC removal } & $\begin{array}{l}\text { A1 = Turbidity; } \\
\text { B1 = Critical } \\
\text { Time }\end{array}$ & 4 & $65.3-0.87 \mathrm{~A} 1+1.4 \mathrm{~B} 1-0.1 \mathrm{~A} 1 \mathrm{~B} 1-5.9 \mathrm{~A} 1^{2}-9 \mathrm{~B} 1^{2}$ & SM & $\mathrm{A} 1^{2}, \mathrm{~B} 1^{2}$ & 57.99 \\
\hline & $\begin{array}{l}\mathrm{A} 2=\mathrm{pH} \\
\mathrm{B} 2=\text { Temperature }\end{array}$ & 4 & $49.9-2 \mathrm{~A} 2+10.7 \mathrm{~B} 2-\mathrm{A} 2 \mathrm{~B} 2-7.3 \mathrm{~A} 2^{2}+1.7 \mathrm{~B} 2^{2}$ & NSM & - & 44.8 \\
\hline \multirow[t]{2}{*}{ Dissolved Oxygen } & $\begin{array}{l}\text { A1 = Turbidity; } \\
\text { B1 = Critical } \\
\text { Time }\end{array}$ & 3 & $4.8-0.16 \mathrm{~A} 1-0.6 \mathrm{~B} 1+0.01 \mathrm{~A} 1 \mathrm{~B} 1-0.4 \mathrm{~A} 1^{2}-0.5 \mathrm{~B} 1^{2}$ & SM & $\begin{array}{l}\mathrm{A} 1, \mathrm{~B} 1 \\
\mathrm{~A} 1^{2}, \mathrm{~B} 1^{2}\end{array}$ & 4.76 \\
\hline & $\begin{array}{l}\mathrm{A} 2=\mathrm{pH} \\
\mathrm{B} 2=\text { Temperature }\end{array}$ & 3 & $4.1-0.12 \mathrm{~A} 2-0.8 \mathrm{~B} 2+0.2 \mathrm{~A} 2 \mathrm{~B} 2+0.3 \mathrm{~A} 2^{2}-0.4 \mathrm{~B} 2^{2}$ & SM & B2 & 4.44 \\
\hline \multirow[t]{2}{*}{ Flow rate $(\mathrm{m} / \mathrm{h})$} & $\begin{array}{l}\text { A1 = Turbidity; } \\
\text { B1 = Critical } \\
\text { Time }\end{array}$ & 2 & $1.26-0.1 \mathrm{~A} 1+0.2 \mathrm{~B} 1+0.02 \mathrm{~A} 1 \mathrm{~B} 1-0.05 \mathrm{~A} 1^{2}-0.06 \mathrm{~B} 1^{2}$ & SM & $\mathrm{A} 1, \mathrm{~B} 1$ & 1.23 \\
\hline & $\begin{array}{l}\mathrm{A} 2=\mathrm{pH} \\
\mathrm{B} 2=\text { Temperature }\end{array}$ & 2 & $2.21+0.4 \mathrm{~A} 2+0.6 \mathrm{~B} 2-0.03 \mathrm{~A} 2 \mathrm{~B} 2+0.08 \mathrm{~A} 2^{2}-0.4 \mathrm{~B} 2^{2}$ & NSM & - & 1.80 \\
\hline \multirow[t]{2}{*}{ pH change } & $\begin{array}{l}\text { A1 = Turbidity; } \\
\text { B1 = Critical } \\
\text { Time }\end{array}$ & 2 & $0.05-0.04 \mathrm{~A} 1-0.15 \mathrm{~B} 1-0.04 \mathrm{~A} 1 \mathrm{~B} 1+0.02 \mathrm{~A}^{2}-0.11 \mathrm{~B} 1^{2}$ & SM & B1 & 0.14 \\
\hline & $\begin{array}{l}\mathrm{A} 2=\mathrm{pH} \\
\mathrm{B} 2=\text { Temperature }\end{array}$ & 2 & $0.25-0.065 \mathrm{~A} 2-0.2 \mathrm{~A} 2 \mathrm{~B} 2-0.3 \mathrm{~A} 2^{2}-0.11 \mathrm{~B} 2^{2}$ & SM & $\begin{array}{l}\mathrm{A} 2 \mathrm{~B} 2 \\
\mathrm{~A}^{2}\end{array}$ & 0.22 \\
\hline \multirow[t]{2}{*}{ MC-LR assay } & $\begin{array}{l}\text { A1 = Turbidity; } \\
\text { B1 = Critical } \\
\text { Time }\end{array}$ & 5 & $1.24-0.13 \mathrm{~B} 1+0.02 \mathrm{~A} 1 \mathrm{~B} 1+0.03 \mathrm{~A} 1^{2}-0.23 \mathrm{~B} 1^{2}$ & SM & $\mathrm{B} 1, \mathrm{~B} 1^{2}$ & 1.30 \\
\hline & $\begin{array}{l}\mathrm{A} 2=\mathrm{pH} \\
\mathrm{B} 2=\text { Temperature }\end{array}$ & 5 & $0.99-0.06 \mathrm{~A} 2-0.12 \mathrm{~B} 2-0.1 \mathrm{~A} 2 \mathrm{~B} 2+0.07 \mathrm{~A} 2^{2}+0.06 \mathrm{~B} 2^{2}$ & NSM & - & 1.06 \\
\hline \multirow[t]{2}{*}{ Electrical conductivity } & $\begin{array}{l}\text { A1 = Turbidity; } \\
\text { B1 = Critical } \\
\text { Time }\end{array}$ & 2 & $235+7.6 \mathrm{~A} 1+0.29 \mathrm{~B} 1+2.3 \mathrm{~A} 1 \mathrm{~B} 1-4.3 \mathrm{~A} 1^{2}-9.8 \mathrm{~B} 1^{2}$ & SM & $\mathrm{A} 1, \mathrm{~B} 1^{2}$ & 222.3 \\
\hline & $\begin{array}{l}\mathrm{A} 2=\mathrm{pH} \\
\mathrm{B} 2=\text { Temperature }\end{array}$ & 2 & NA & NA & NA & NA \\
\hline Optimized condition & $\begin{array}{l}\text { Turbidity }=12 \\
\text { NTU }\end{array}$ & $\begin{array}{l}\text { Time: } \\
2.16 \text { Hour }\end{array}$ & $\mathrm{pH}=7.04$ & Temperature $=14.8^{\circ} \mathrm{C}$ & $\begin{array}{l}\text { Overall desi } \\
0.638\end{array}$ & bility: \\
\hline
\end{tabular}

${ }^{1}$ Turbidity level: 10 NTU, 20 NTU and 30 NTU; Critical Time: $1 \mathrm{hr}, 2 \mathrm{hr}$ and $4 \mathrm{hr}$; pH level: 6,7 and 8 ; Temperature: $10^{\circ} \mathrm{C}, 20^{\circ} \mathrm{C}, 30^{\circ} \mathrm{C}$.

using sand particle size in the range: $2-4 \mathrm{~mm}$. Rest $120 \mathrm{~mm}$ was used as the headspace for allowing the influent water. Grain size-distribution analysis and related calculations for the sand particles are detailed in the supplementary file (Table S1 and Fig. S3). Table 2 shows details of the strains used in the column filters and characteristics of the source water used as an influent to the filters. A good filter should be capable of handling other water quality parameters as well apart from MCs. The purpose of each filter was defined to evaluate the potential of individual MC-LR-degraders and when they are co-cultured with the native bacterial strains $(\mathrm{X})$ present in the filtration unit of the DWTP, in removing MC-LR and other water quality parameters (WQPs). One column filter was used as the negative control (without any bacterial strain, control filter (C) to differentiate for the MC-LR removal due to adsorption and biodegradation (Table 2). Knowing the importance of the control filter ${ }^{10}$, a replica column was installed too in parallel where the results were verified with each other in order to remove any ambiguous experimental error (over/under estimation of results). Also, one filter inoculated with the native bacterial strains isolated from the DWTP filtration unit (filter X), was simulated to represent a DWTP sand filter. The result obtained from this filter (X) further allowed to evaluate for the difference in MC-LR degradation and other WQPs when $\mathrm{X}$ was co-cultured with MC-LR-degraders (A + X, B + X and S + X).

Before the filter operation, the plug-flow condition was ensured (no air bubble and initial head loss) by determining the Morrill

\footnotetext{
${ }^{10}$ To discriminate the removal of MC-LR by adsorption from biodegradation.
} 


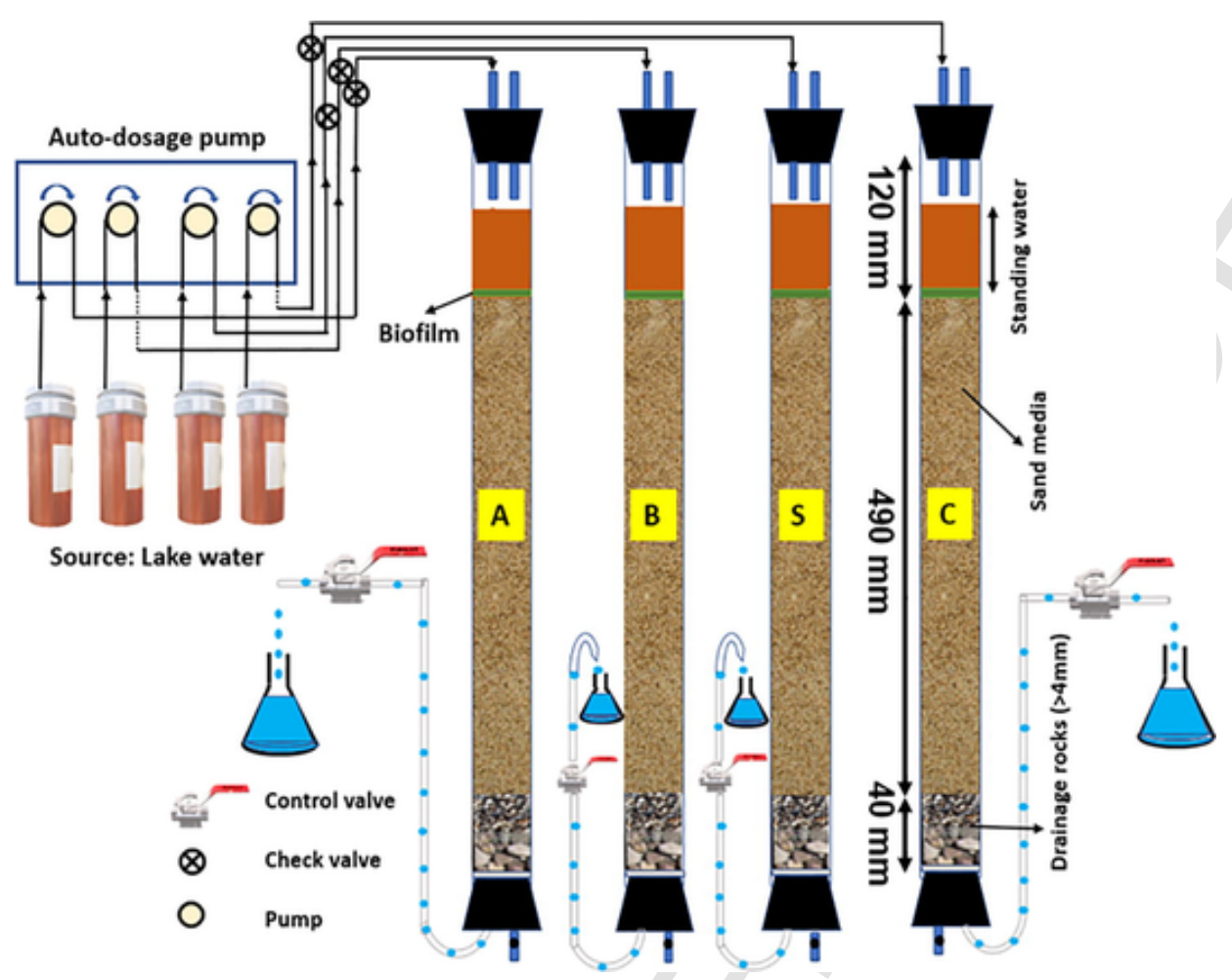

Fig. 2. Detailed schematic representation of laboratory column-setup (only 4 shown here, in actual eight filters present).

Table 2

Details of inoculated filters (eight) and characteristics of the source water used as an influent to these filters.

\begin{tabular}{|c|c|c|c|c|c|c|c|c|}
\hline Filter & A & B & $\mathrm{S}$ & $\mathrm{X}$ & $\mathrm{C}$ & $A+X$ & $\mathrm{~B}+\mathrm{X}$ & $S+X$ \\
\hline Strain inoculated & $\begin{array}{l}\text { Arthrobacter ramosus } \\
\text { (A) }\end{array}$ & $\begin{array}{l}\text { Bacillus sp. } \\
\text { (B) }\end{array}$ & $\begin{array}{l}\text { Sphingomonas sp. } \\
\text { (S) }\end{array}$ & $\begin{array}{l}\text { Pseudomonas fragi }+ \text { Chryseobacterium } \\
\text { sp. (X) }\end{array}$ & No bacteria & $A+X$ & $B+X$ & $S+X$ \\
\hline $\begin{array}{l}\text { MDI }^{1} \text { (after } 8 \\
\text { cycles) }\end{array}$ & 2.38 & 2.23 & 2.47 & 2.54 & 2.12 & 2.76 & 2.56 & 2.54 \\
\hline $\begin{array}{l}\text { Toxicity (eq. DMSO } \\
\%)\end{array}$ & 8.3 & 13 & 5.8 & 9.1 & 16 & 0.6 & 6.7 & 0.2 \\
\hline $\begin{array}{l}\text { Degradation } \\
\text { contribution }\end{array}$ & $17 \%$ & $14 \%$ & $21 \%$ & $21 \%$ & $0 \%{ }^{2}$ & $31 \%$ & $21 \%$ & $38 \%$ \\
\hline SUVA $\left(\mathrm{m}^{-1}-\mathrm{L} / \mathrm{mg} \mathrm{C}\right)$ & 2.6 & 3.27 & 2.66 & 2.98 & 3.57 & 2.83 & 2.76 & 2.23 \\
\hline \multicolumn{9}{|c|}{ Source water characteristics } \\
\hline $\mathrm{pH}$ & Alkalinity & $\mathrm{NH}_{4}{ }^{+} \mathrm{NO}_{2}$ & $\mathrm{Al} / \mathrm{As} / \mathrm{Ba}$ & $\mathrm{NO}_{3}^{-}$ & Conductivity & $\mathrm{UV}_{254}$ & $\begin{array}{l}\mathrm{DOC} / \mathrm{COD} \\
(\mathrm{ppm})\end{array}$ & SUVA \\
\hline 6.46 & $18 \mathrm{mg} / \mathrm{L}$ as $\mathrm{CaCO}_{3}$ & $\begin{array}{l}2.4 \mathrm{ppm} / \\
\text { zero }\end{array}$ & $0.13 /<0.01 \mathrm{ppm}$ & $4.4 \mathrm{ppm}$ & $234 \mu \mathrm{S} / \mathrm{cm}$ & 0.465 & $9.6 / 36.3$ & 3.52 \\
\hline
\end{tabular}

$1 \mathrm{MDI}=$ Morill Dispersion Index (MDI $=1$ for ideal plug flow condition, MDI $=23$ for the completely stirred reactor).

${ }^{2}$ Normalizing value of control (56\%), therefore assigned the value of MC-LR removal contribution set to zero.

dispersion index (all filter showed MDI of near $2.5^{11}$ ). Each filter was separately inoculated with the respective strains for a continuous period of 2 weeks (Table 2). The inoculum was prepared in the nutrient water of $800 \mathrm{mg} / \mathrm{L}-\mathrm{COD}$ (recipe details provided in the supplementary section: Tables S3 and S4), to allow for a quick establishment of the biofilm over the sand media (as done for screening test). About $50 \mathrm{~mL}$ of inoculum was passed every 4-h (recirculation mode) allowing substantial contact time between the bacteria and the sand media to form quick microcolonies. The inoculum was replenished with nutrients every

${ }_{11} \mathrm{MDI}=$ Morrill Dispersion Index $(\mathrm{MDI}=1$ for ideal plug flow condition, $\mathrm{MDI}=23$ for the completely stirred reactor) two days, each time reducing COD by $100 \mathrm{mg} / \mathrm{L}$ to obtain $190 \mathrm{mg} / \mathrm{L}^{12}$ by day 12 . As compared to the model reactor that was used for the screening purpose, the inoculation during the filter column operation was performed with 10 times more concentration of biocells, i.e., $6 \times 10^{8}$ cells/ $\mathrm{mL}$ (because 10 times more sand media was used).

The biofilm formed over the sand media was periodically quantified by analyzing parameters, such as the flow rate, DOC removal, protein concentration and cell viability (discussed in more details in Section 3.3). After the successful biofilm formation, all eight filters were run continuously for 8 cycles with each cycle comprising 7 days using

\footnotetext{
${ }^{12}$ To get closer to lake water COD, otherwise bacteria can get shock during filter operation once biofilm gets formed.
} 
lake water. The flow rate was measured by maintaining a constant head of $5 \mathrm{~cm}$ of standing water each time the measurement was recorded. Protein concentration was determined by a method similar to the CV assay (Section 2.2) except that the sand sample was vortexed in the cell-lysis buffer to extract complete protein: recipe in supplementary file). The sample was centrifuged at $10,000 \times g$ for $2 \mathrm{~min}$ and the supernatant was measured for the protein concentration by Bradford assay [23]. Cell viability was measured through MTT assay as mentioned in Section 2.2.

No previous history of microcystin or cyanobacterial bloom was reported for the lake water (result details of various microcystin and other cyanotoxin analysis are provided in the supplementary section: Table S2). Table 2 lists the environmental parameters of the lake water. Based on the empty bed contact time (EBCT), all the filters were run continuously during the day and evening time (9AM to $10 \mathrm{PM})$. During the night hours (11 PM to 8AM), influent uptake was auto-programmed such that during any time, the gap between two influent charges did not exceed the critical filter charge period or CSTI $(2.16 \mathrm{~h}-135 \mathrm{~min})$ as obtained from the optimization experiment.

The backwash operation was performed once, after the end of the 4 th cycle, at $10 \%$ bed expansion for $5 \mathrm{~min}$. This was conducted to simulate the DWTP filters that are routinely backwashed to remove any algal growth and air-bubbles (can increase the head loss thereby affecting the removal of contaminants). All pipelines and connectors were washed every 2 cycles to remove any deposited particles/biofilm.

\subsection{Sample analysis}

\subsubsection{Coliform removal, turbidity removal, DOC removal, nitrate, nitrite,} and ammonia

Total coliforms in the effluent or filtered water were determined using the membrane filtration technique every 3 days (twice/cycle) according to the Standard Methods (APHA, 1998) [24]. The number of coliforms present in the effluent of each filter was reported as CFU/100 mL and compared with the total coliform present in the influent water (lake water). The average $\mathrm{CFU} / 100 \mathrm{~mL}$ observed for the source water (averaging 9 samples) was $2401 \pm 312 \mathrm{CFU} / 100 \mathrm{~mL}$. The percentage removal of total coliform was calculated by Eq. (1) as follows:

$\left(\frac{2401 \pm 312 \mathrm{CFU} / 100 \mathrm{~mL}-\text { Total coliform in filtered water sample } / 100 \mathrm{~m}}{2401 \pm 312 \mathrm{CFU} / 100 \mathrm{~mL}}\right.$
$\times 100$

The turbidity of the filtered water was determined every day using HACH instrument 2100 model. To mimic the optimized initial turbid condition (13 NTU from optimization study), the lake water was appropriately mixed using turbid concentration of hydrated clay solution as described by Asrafuzzaman et al. (2011) [25]. It must be noted that the initial turbidity of the lake water was lower (6 NTU) than the optimized turbidity value (13 NTU) and hence the above activity was performed. The average turbidity of the filtered effluent for each cycle was reported in NTU and the removal was calculated by Eq. (2):

$\underline{13 \pm 2.2 \mathrm{NTU}-\text { turbidity of filtered water sample (NTU) }}$

$\times 100$

$$
13 \pm 2.2 \mathrm{NTU}
$$

Around $30 \mathrm{~mL}$ of the sample before and after filtration was filtered using $0.45 \mu \mathrm{m}$ glass-fiber filter. DOC of the resultant solution was determined using a Shimadzu 5000A analyzer (Shimadzu, Japan). DOC was estimated twice a cycle and was reported in $\mathrm{mg} / \mathrm{L}$. Based on the DOC value and the UV 254 value (UVA), specific UV absorbance value termed as SUVA was reported (UVA 254/DOC) to give an indirect estimation of the NOMs removal.

Nitrate, nitrite, and ammonia were determined in the effluent sample as described by Naghdi et al. (2017) [26]. An influent lake water solution was prepared to contain $100 \mathrm{mg} / \mathrm{L}$ of nitrate, $10 \mathrm{mg} / \mathrm{L}$ of nitrite and $2 \mathrm{mg} / \mathrm{L}$ of ammonia-N at the end of each cycle ${ }^{13}$, where the filtered sample was determined for nitrate, nitrite, and ammonia-N. Prior to the solution preparation for the required initial concentration, nitrate, nitrite and ammonia were determined in the lake water.

\subsection{2. $p H$, dissolved oxygen, conductivity}

The $\mathrm{pH}$ was measured every two days (three times a cycle) and the average value of each cycle was reported for each filter. Also, dissolved oxygen was reported every two days (thrice a cycle) using a portable F4-Standard probe (Mettler Toledo Inc) to check the water quality (no anoxic condition build-up). The electrical conductivity of the filtered effluent was measured every two days using Mettler Toledo ${ }^{\mathrm{TM}}$ S230 SevenCompact ${ }^{\mathrm{TM}}$ Conductivity Meter.

\subsubsection{Flow rate, toxicity assay and MC-LR analysis}

The flow rate of each filter was reported in $\mathrm{m} / \mathrm{h}$ (or $\mathrm{m}^{3} / \mathrm{m}^{2} / \mathrm{h}$ ) after the end of each cycle. Backwashing was done after the end of the 4th cycle when the flow rate reduced to at least $35 \%$ as compared to the 1 st cycle. Head of the standing water during flow rate measurement was kept constant at around $115 \mathrm{~mm}$.

MC-LR toxicity assay was performed on the filtered sample. A similar protocol was followed as described in Kumar et al. (2018) [21] to report on the relative toxicity of the MC-LR-spiked treated filtered samples in terms of equivalent dimethyl sulfoxide (eq. DMSO). In brief, the relationship between viability of the bioindicator cells (Rhizobium meliloti) and various \% DMSO (v/v) solution was established. The viability was measured in terms of spectrophotometric absorbance using MTT assay. Similarly, the relationship was established for MC-LR (92-1500 $\mu \mathrm{g}$ / L). To report the equivalent \% DMSO (v/v) for the MC-LR concentration, the absorbance value of both the relationship curve was linked with each other and sample toxicity assay was reported in \% equivalent DMSO. The equivalent \% DMSO can be defined as the similar mortality effect on the bioindicator cells as a MC-LR solution of specific concentration will have on it. However, it has to be noted that the margin of spectrophotometric absorbance values was very close to the tested MC-LR concentration range and thus the results need further validation using ELISA assay [27].

To determine the MC-LR concentration, the filtered water was collected and prepared for the ultra-high-performance liquid chromatography (UHPLC) analysis as described in Fayad et al. (2015) [28]. For every cycle, average MC-LR removal (using two replicas) was determined for each filter. Briefly, a $20-\mu \mathrm{L}$ sample aliquot was analyzed by UHPLC coupled to a Thermo Q-Exactive Orbitrap mass spectrometer through a positive electrospray ionization source. MC-LR was detected in full scan MS mode (resolution set at 70,000 FWHM at $200 \mathrm{~m} / \mathrm{z}$ ) and quantified against a matrix-matched lake water calibration curve. The limit of quantification (LOQ) was set at the lowest concentration of the calibration curve (i.e., $0.1 \mu \mathrm{g} / \mathrm{L}$ ). To distinguish the contribution of adsorption from the biological process for the MC-LR removal, the result of filter C (which represents MC-LR removal only due to adsorption), was subtracted. To determine the MC-LR degradation exclusively due to biodegradation, this value was further subtracted from undegraded or residual MC-LR (determined from UHPLC analysis).

\subsection{Bio-profiling of column filters and SEM imaging}

After the end of 8 cycles of filter run (7days/cycle), sand from each column filter was carefully dropped by gravity and collected for every $5 \mathrm{~cm}$ as shown in Supplementary Fig. S4. For each of these sand

\footnotetext{
${ }^{13}$ Stock solution of sodium nitrate, sodium nitrite and ammonium sulphate were prepared based on the stoichiometric equation for nitrate, nitrite and ammonia- $\mathrm{N}$, respectively.
} 
samples collected, the biofilm was quantified in terms of the bioactivity (quantified as cell viability) and biomass using MTT assay and CV assay, respectively, as described in Section 2.2. Before and after the biofilm formation over the sand media, the SEM micrographs were captured at $10 \mathrm{kV}$ accelerating voltage (Zeiss EVO ${ }^{\circledR} 50$ Smart SEM system).

\subsection{Statistical analysis}

All statistical analyses comprising standard deviation, average, student $t$-test, $\mathrm{p}$-value comparison, and all graphical presentations were performed using ORIGIN software (Version 8.5; OriginLab).

\section{Results and discussion}

\subsection{Screening of the bacterial strains}

Three MC-LR-degraders (A, B and S) were subjected to biofilm formation test over the sand media (Fig. 1). Positive control in the form of $S$. epidermidis was also placed in parallel with the three strains, and biofilm quantification of these stains was compared. Negative control of the experiment comprised the sand media and no passage of bacterial inoculum (only nutrient water; arrangement not shown in Fig. 1). Fig. 3 (A) and (B) shows the CV and MTT assay results which depict the spectrophotometric absorbance comparison among all the tested strains.

CV assay: The formed biomass (CV assay) showed a continuous increase for all the strains as the time progressed, except for the Sphingomonas sp. which showed an increase in the absorbance value till day 16 , followed by a decrease on day 19 . This decrease in biomass or the Sphingomonas sp. is also reflected by a decrease in the viable cells between day 16 and day 19 (Fig. 3(B)). This might indicate that apart from the decrease in the bacterial cells (live cells as observed from the MTT assay), other biological molecules, such as DNA, protein and polysaccharides present or involved in the biofilm formation ceased its formation too. As compared to the positive control, all three MC-LR-degraders showed almost similar biomass quantification (in terms of cell biomass: polysaccharides, DNA, proteins, and other biological molecules within the biofilm). However, the viability of the bacteria present in the formed biofilm was specifically observed through the MTT assay results.

MTT assay: All the three tested MC-LR-degraders showed similar or higher cell viability than the positive control (Fig. 3(B). However, the cell viability showed a decrease on day 19 (from day 16) for all the strains and can be attributed to the loss of food and nutrients.

Statistically speaking, all the three MC-LR-degraders showed comparable results to the positive control (Fig. 3(A and B)). When compared to the positive control, p-value for A.ramosus, Bacillus sp., and Sphingomonas sp. for CV assay was found to be $0.84,0.22$ and 0.72 , respectively. For the MTT assay, the corresponding p-values ${ }^{14}$ were reported as 0.52, 0.19 and 0.41. Though Bacillus sp. showed less potential in forming biofilm as compared to the other MC-LR-degraders, still the p-value was found to be almost four times higher than the critical p-value $(0.19>0.05)$. Thus, the null hypothesis was accepted (i.e., Bacillus sp. forms comparative biofilm to $S$. epidermidis: positive control). As a result, all three MC-LR-degraders were continued for further experiments.

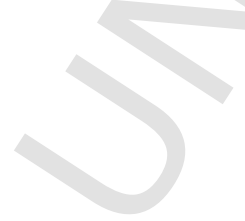

${ }^{14}$ For the p-value listed, the absorbance values obtained (including 3 replicas) for all the five points (day 3 , day 7 , day 11 , day 16 and day 19) were compared to the positive control. It was performed for all the three MC-LR-degraders tested. Hence, all the points were covered.

\subsection{Optimization of input parameters using the CCD technique}

The optimized-parameter obtained using the CCD technique (Design-Expert 7.0) was found to be $7.06,15.3^{\circ} \mathrm{C}, 2.16 \mathrm{~h}, 13 \mathrm{NTU}$. Table 1 shows the optimization experiment results based on the obtained output parameters (desirability index $=0.638$ ) as mentioned in Section 2.3. All the significant, as well as non-significant models (compared with F-value and p-value of the model) along with the equation and desired output values, are listed in Table 1 . For the input variable, turbidity (A1) and standby time (B1), all models defining the output parameters were found to be significant (Prob $>$ F, values not shown in Table 1), except the coliform removal test. This indicates the importance of CCD to optimize and know the proper (optimized) conditions rather than choosing a random value. However, the coliform removal model showed significant p-value $0.0149(<0.05)$ for "standby time" parameter (B1) as compared to an overall p-value of the model $0.13(>0.05)$. This observation can be simply explained by the fact that under the influent flow condition, bacteria are strongly attached when more time is allowed for the bacteria to interact with the adsorbing media and vice-versa (probably, this is the reason why parameter $\mathrm{B} 1$ and $\mathrm{B}^{2}$ are not in the equation). In every model defined in Table 1 for the optimization study of turbidity (A1) and time (B1), "time factor" (B1) played a crucial role. Thus, under no condition, critical stand-by time should exceed the optimized value $(2.16 \mathrm{~h})$ during the filter operation and care was taken for the same.

On the other hand, optimization study was done for the input parameters, pH (A2) and temperature (B2), only two output parameter models, i.e., dissolved oxygen and $\mathrm{pH}$ change were relevant. This meant that many output variables did not get affected by a $\mathrm{pH}$ range of 6-8 and temperature range of $10^{\circ} \mathrm{C}-30^{\circ} \mathrm{C}$. However, dissolved oxygen and $\mathrm{pH}$ form an integral aspect of drinking water treatment, and hence the optimized value was followed in any case for the rest of the experiments. Response surface methodology plots for all the models are included in the supplementary section (Fig. S5).

\subsection{Biofilm formation}

All the filters were run for 8 weeks ( 8 cycles) post-biofilm formation over the sand media. It took 14-16 days for the mature biofilm to get formed over the sand media. As mentioned in Section 2.4, a high inoculum concentration of $6 \times 10^{8}$ cells $/ \mathrm{mL}$ (divided equally among two or more bacterial strains for co-culture case) was used to inject the column filter. This high cell concentration allowed to attain a critical biomass concentration exceeding the level of endemic or other indigenous bacteria (present in lake water) which might have grown over the sand surface and thereby could affect the study objective. Bourne et al. (2006) [16] showed that high cell inoculation $\left(10^{7} \mathrm{cells} / \mathrm{mL}\right)$ aided the MC-degraders in increasing their chance of survival under the presence of the indigenous bacterial community. Also, it was observed that MC-LR-degraders possessing the $m l r A$ gene competed, even at bacterial concentration of $100 \mathrm{CFU} / \mathrm{ml}$, with other bacteria present in the lake water.

However, Bourne et al. (2006) [16] achieved enhanced biodegradation of MCs even at $10^{2}-10^{5}$ cells $/ \mathrm{mL}$ which signified that effective bacterial cell attachment is also necessary for the MCs degradation. Nevertheless, high inoculation might have increased the chance of survival of the inoculated MC-LR-degraders and lowered the acclimatization period for a filter to become mature (biofilm formation) in removing MC-LR.

Also, as mentioned by Wang et al. (2007) [13], the sand particle may even take $>6$ months to establish a mature biofilm for particle size as high as $1000-1400 \mu \mathrm{m}$. However, in the current study, the effective diameter of the sand grain was $<200 \mu \mathrm{m}$, and with high inoculation, it just took 16 days to establish a mature biofilm. However, different 

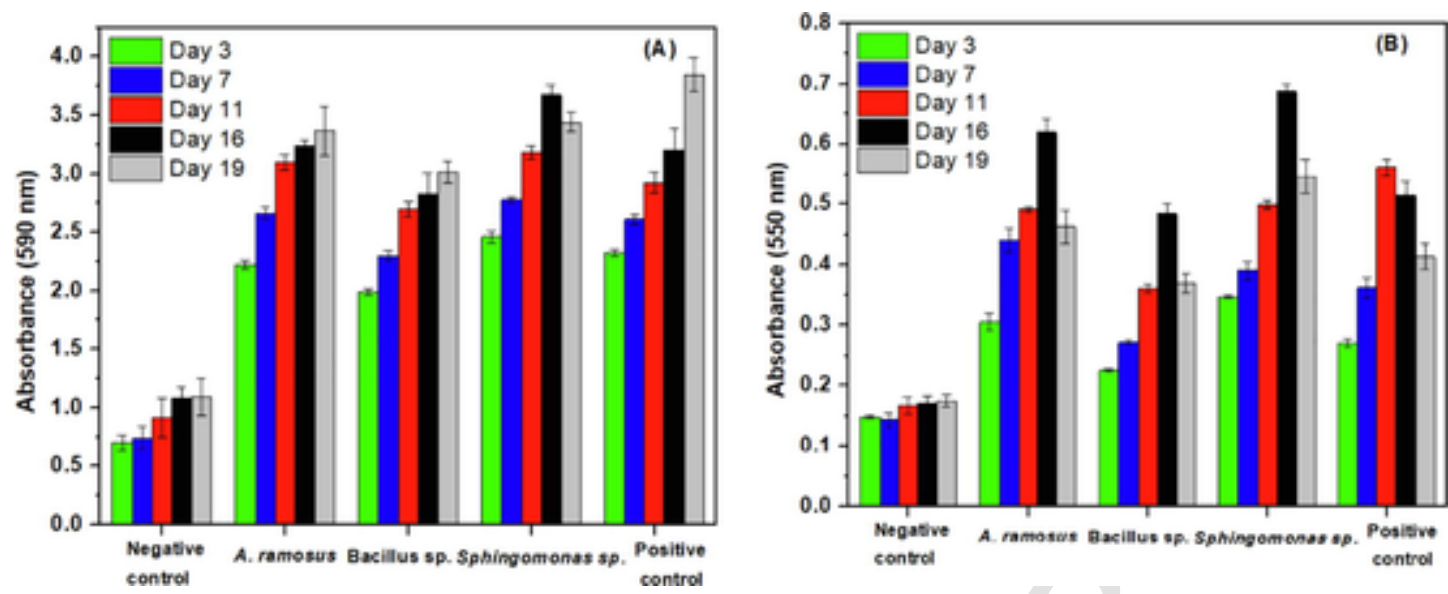

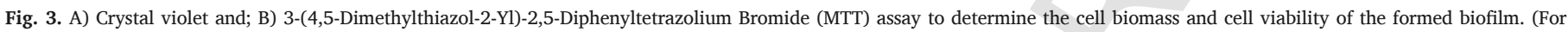
interpretation of the references to color in this figure legend, the reader is referred to the web version of this article.)

bacterial species take a distinct period for biofilm establishment. Fig. 4(A), (B), (C) and (D) shows the flow rate, DOC removal, protein and cell viability measure for all the filters as the biofilm starts getting formed (day 1-day 16). Successful biofilm formation was evident from the fact that DOC removal kept increasing till day 16 for all the biosand filters as compared to the control filter (filter C: only sand). As compared to the control sand filter ( $<30 \%$ DOC removal), maximum DOC removal was achieved by filter $S+X(\sim 60 \%)$ and filter S ( $\sim 50 \%)$, so that Sphingomonas sp. performed well in degrading organic carbon which is one of the primary objectives of the drinking water filter. Balkwill et al. (2006) [29] observed moderate sugar/glucose utilization (COD removal) by Sphingomonas sp. even under low nutrient conditions. This holds a strong prospect of utilizing and preferring such MC-LR-degrader to other aerobic ones which showed a strong inability to survive under low nutrient conditions (filter conditions).

The formation of biofilm in each filter continuously reduced the flow rate (Fig. 4(A)). As compared to the control filter, (where a maximum reduction in the flow rate was just $13 \%$ ), filter: $S+X$ and $S$ showed a drastic reduction of $>70 \%$, possibly due to more biomass production as is evident from the CV assay too (Fig. 3(A)). A very slow rate of backwashing (without much disturbing the attached biofilm) was performed on the 14th day after which the flow rate increased slightly for all filters at the expense of a decrease in the DOC removal (on an average $5 \%-10 \%$ decrease for every filter). In general, co-cultured biosand filters $(\mathrm{A}+\mathrm{X}, \mathrm{B}+\mathrm{X}$ or $\mathrm{S}+\mathrm{X})$, enhanced $\mathrm{DOC}$ removal than their individual counterpart strains (A, B or S) (Fig. 3(B)). A decrease in the protein level (Fig. 3(C)) and cell viability (Fig. 3(D)) after 14 days for some filters, provided evidence of mature biofilm formation over the sand media. The biofilm formed in filter $S+X$ and filter $S$ showed the highest protein and cell viability among all filters, indicating the presence of a more active enzyme to carry out the MC-LR degradation.

\subsection{Routine sample analysis after biofilm formation}

Backwashing was performed for all the filters after the end of the 4th cycle which helped in an increase in the flow rate without compromising much of the biofilm. Lowest flow rate $(0.15 \pm 0.06 \mathrm{~m} / \mathrm{h})$ was observed for $\mathrm{S}+\mathrm{X}$ filter and all the individual strain filters showed higher flow rate when compared to their co-cultured counterparts (Fig. 4(A)). Filter $\mathrm{C}$ showed the highest flow rate $(1.62 \pm 0.3 \mathrm{~m} / \mathrm{h})$ unsurprisingly, due to no inoculation of bacterial cells.

The lowest and highest coliform removal of $48 \pm 10.7 \%$ and $81 \pm 4.7 \%$ was obtained for filter $C$ and filter $S+X$, respectively. Filters inoculated with co-culture strains showed higher coliform removal than their individual counterparts highlighting competition and entrapment of the coliform bacteria assisting in their removal. Filter $\mathrm{X}$ representing the DWTP filtration unit, achieved a moderate coliform removal of $60 \pm 4 \%$. It may be noted that the filtered water is to be further treated in the disinfection unit of a DWTP. The disinfection unit can remove $99.9 \%$ of coliforms and hence, coliform removal of $>80 \%$ seemed promising. Also, the source water was used in the same form as it was delivered, and no further dilution was made. Thus, all load was taken by the filter unit since the source water was not subjected to any pre-treatment (pre-ozonation or coagulation/flocculation) during the experiment.

Initial DOC concentration of source water was $9.6 \mathrm{mg} / \mathrm{L}$. Highest DOC removal of $33 \pm 2.1 \%$ was achieved by filter $S+X$ which was $19 \%$ more than the control filter $\mathrm{C}$. On the other hand, other co-cultured inoculated filters $(\mathrm{X}, \mathrm{A}+\mathrm{X}, \mathrm{B}+\mathrm{X})$ showed higher DOC removal than the control but not more than $29 \%(A+X)$. It must be noted that the biodegradation efficiency of MCs also depends on the biodegradable carbon source (in the form of DOC or TOC ${ }^{15}$ ) present in the influent water. Eleuterio et al. (2010) [30] demonstrated an interesting result where TOC ( $>30 \mathrm{mg} / \mathrm{L}$ ) acted as a hindrance to MC degradation (MC degradation started only after $>90 \%$ TOC removal happened) as the bacterial cells (isolated from biofilter of a DWTP) might prefer other carbon sources over MCs. In contrast, this study maintained a balanced removal of both DOC and MCs for every inoculated filter (Section 3.5). Also, the lowest SUVA value for the filtered sample obtained from filter $\mathrm{S}+\mathrm{X}$ as compared to other filters set-up (see Table 2) offers a good platform for the filtered water to undergo treatment in the next unit (disinfection unit). We expect that the formation of disinfection-by-products increases with increase in SUVA value (more SUVA means a higher natural organic matter is present) [31].

Turbidity removal can be indirectly correlated with the bioactivity in a filter (more bioactivity and more biomass). This biomass could be responsible for the entrapment of suspended particles as is demonstrated by the control filter $\mathrm{C}$ which showed the highest turbidity of 3.9 NTU as compared to below guideline values (1-3 NTU) of 1.23 NTU obtained for filter $\mathrm{S}+\mathrm{X}$. The bioactivity of filter $\mathrm{C}$ as compared to other inoculated-filters suggests that it has always remained less effective as is evident from DOC and MC-LR removal. Also, the dissolved oxygen can be cited as an indicator of the high bioactivity in the inoculated filters ( $>5 \mathrm{mg} / \mathrm{L}$ for control filter $\mathrm{C}$ as compared to $<3.5 \mathrm{mg} / \mathrm{L}$ for all inoculated filters).

All the filters achieved more than 90\% removal of nitrite, however, only filter $\mathrm{S}+\mathrm{X}$ met the final nitrite guideline value of $<3 \mathrm{ppm}$.

${ }^{15}$ Total organic carbon 

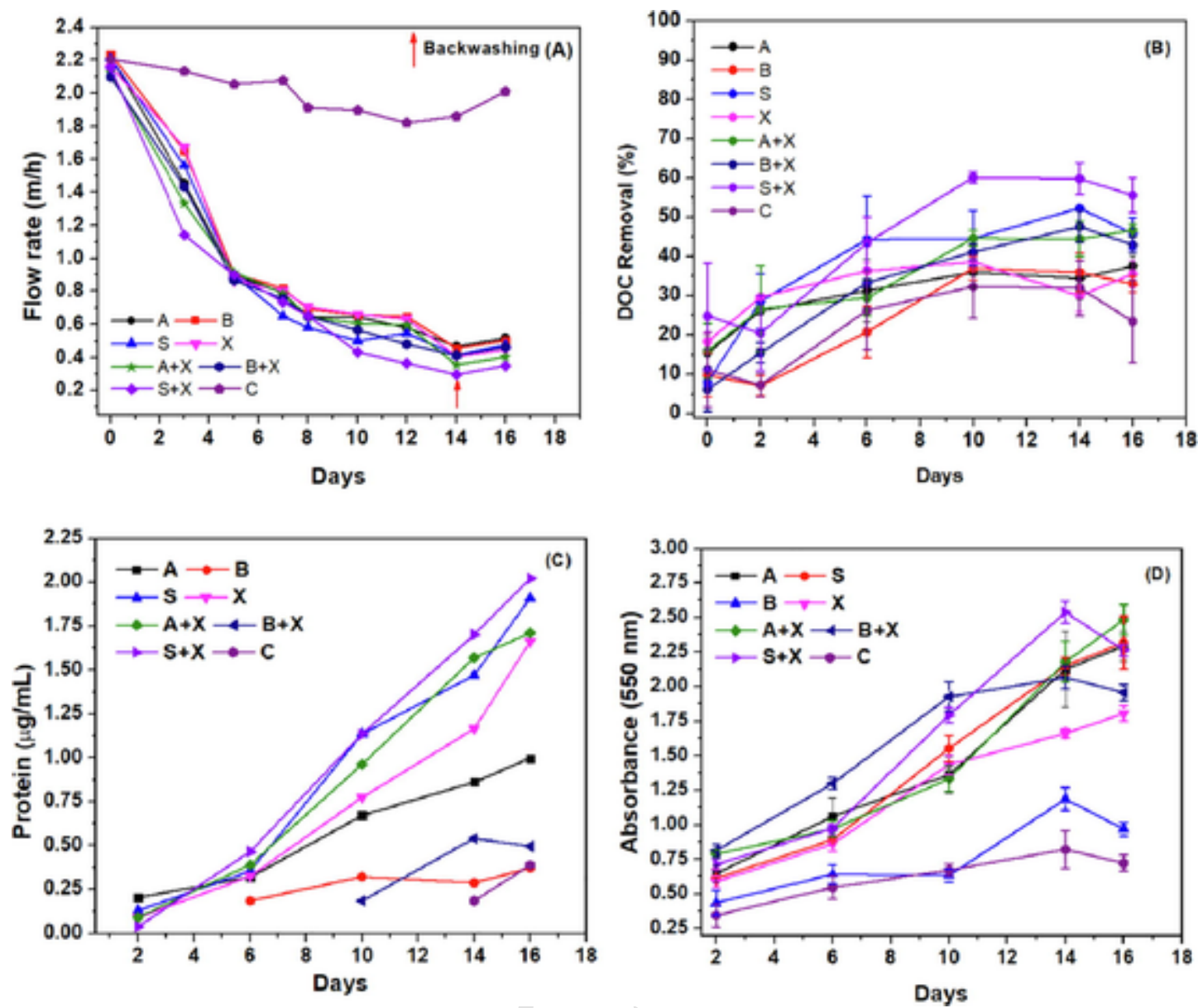

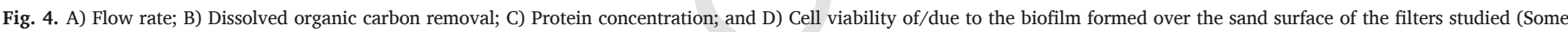
points in Fig. 4 (C) is missing for filter B, B $+\mathrm{X}$ and control as protein formed was too less to quantify for the amount of sand sampled).

For the nitrate removal, except for filter B, X, C, all other filters achieved the guideline value of $<45 \mathrm{ppm}$. On the other hand, for the ammonia- $\mathrm{N}$ removal, except for the filter $\mathrm{S}+\mathrm{X}$, none of the filters achieved the strict guideline values of $<0.121 \mathrm{ppm}$. Overall, the nitrification process was not affected by the DO limitation within the filters as the values mostly remained in the range of $2-4 \mathrm{mg} / \mathrm{L}[32]$.

\subsection{MC-LR removal and toxicity assay}

Fig. 5 shows the stack-bar chart representation of the MC-LR removal (comprising 8 cycles) for all 8 filters, in terms of adsorption and biodegradation along with the residual MC-LR percentage in the treated (filtered) water. Highest average MC-LR removal of $87.6 \pm 10 \%$ and $94.2 \pm 6.8 \%$ was achieved by the co-cultured inoculated sand filter, $\mathrm{A}+\mathrm{X}$, and $\mathrm{S}+\mathrm{X}$, respectively. The reported result was compared with the control filter $C(56.5 \pm 9.9 \%)$, to differentiate the MC-LR removal due to biodegradation and adsorption. Co-cultured strains $\mathrm{A}+\mathrm{X}$ and S + X enhanced the MC-LR removal by $31 \%$ and $38 \%$, respectively.

It must be noted that the MC-LR removal presented in Table 3 was accounted for only when biofilm was formed in all the filters (except filter C). Also, since the lake water was the influent matrix during the filter operation, minor biofilm formation seemed inevitable after 2 weeks (or 2 cycles), even in the control filter (filter $\mathrm{C}$ ). This minor biofilm formation in filter C (uninoculated filter) can be attributed to the proliferation of heterogenous bacteria present in the lake water. If we compare the MC-LR removal of the control filter before the

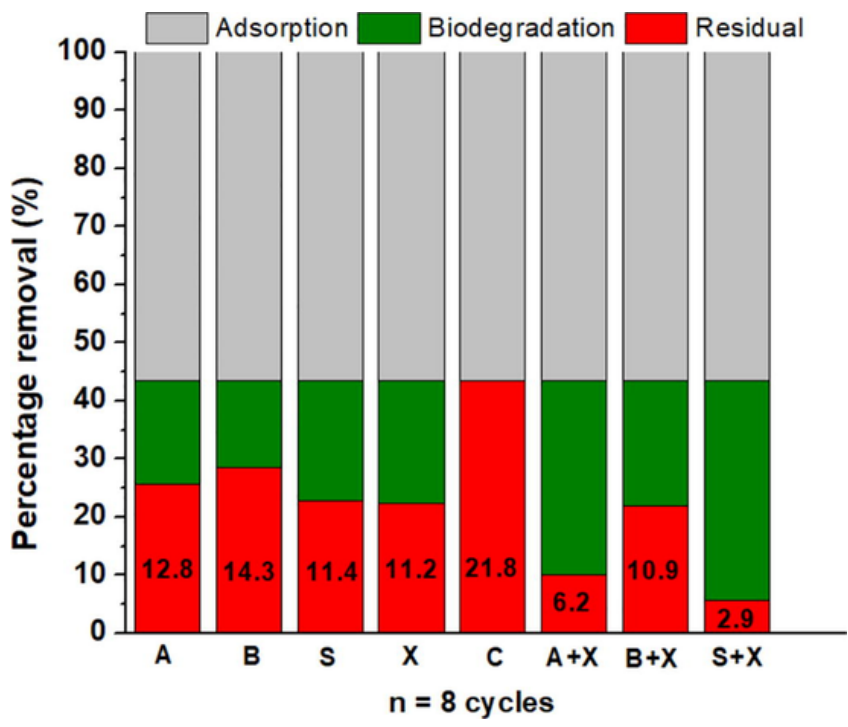

Fig. 5. Stack-bar graph representing the MC-LR removal (in percentage and averaged value for $\mathrm{n}=8$ cycles)) due to adsorption (in grey), biodegradation/biosorption (in green) and the residual/unremoved MC-LR (red bar) in treated (filtered) water sample for each filter. The values inside the lower stack bar represents the MC-LR concentration $(\mu \mathrm{g} / \mathrm{L}) \mathrm{left}$ unremoved. (For stack graph showing the results of every cycle, refer to Fig. S6). (For interpretation of the references to color in this figure legend, the reader is referred to the web version of this article.) 
Table 3

Performance evaluation of output parameters for all the tested filters.

\begin{tabular}{|c|c|c|c|c|c|c|c|c|c|c|}
\hline Filter & $\begin{array}{l}\text { Turbidity } \\
\text { (NTU) }\end{array}$ & $\begin{array}{l}\text { Flow rate } \\
(\mathrm{m} / \mathrm{h})\end{array}$ & $\mathrm{pH}$ & $\begin{array}{l}\text { Dissolved Oxygen } \\
\text { (ppm) }\end{array}$ & $\begin{array}{l}\text { DOC } \\
\text { removal (\%) }\end{array}$ & $\begin{array}{l}\text { Coliform } \\
\text { removal (\%) }\end{array}$ & $\begin{array}{l}\text { MC-LR } \\
\text { removal \% }\end{array}$ & $\begin{array}{l}\text { Nitrate } \\
\text { (ppm) }\end{array}$ & $\begin{array}{l}\text { Nitrite } \\
\text { (ppm) }\end{array}$ & $\begin{array}{l}\text { Ammonia } \\
\text { (ppm) }\end{array}$ \\
\hline A & $2.1 \pm 0.2$ & $0.34 \pm 0.06$ & $6.7 \pm 0.15$ & $3.3 \pm 0.1$ & $21 \pm 10.1$ & $52 \pm 16.7$ & $\begin{array}{l}74.3 \pm 5.3 \\
(7.1)\end{array}$ & 31.5 & 7.18 & 0.21 \\
\hline B & $3.2 \pm 0.6$ & $0.39 \pm 0.04$ & $6.7 \pm 0.13$ & $3.4 \pm 0.1$ & $22 \pm 6.5$ & $63 \pm 12.3$ & $\begin{array}{l}71.1 \pm 6.4 \\
(13.1)\end{array}$ & 46.8 & 6.81 & 0.14 \\
\hline$S$ & $2.1 \pm 0.8$ & $0.29 \pm 0.05$ & $7.1 \pm 0.13$ & $2.7 \pm 0.1$ & $28 \pm 7.4$ & $69 \pm 10.5$ & $\begin{array}{l}77.1 \pm 7.9 \\
(5.2)\end{array}$ & 34.0 & 6.46 & 0.21 \\
\hline $\mathrm{X}$ & $2.3 \pm 0.6$ & $0.27 \pm 0.07$ & $6.7 \pm 0.13$ & $3.2 \pm 0.2$ & $22 \pm 8.7$ & $73 \pm 10$ & $\begin{array}{l}77.5 \pm 7.8 \\
(9.2)\end{array}$ & 49.4 & 4.75 & 0.14 \\
\hline$A+X$ & $1.9 \pm 0.9$ & $0.23 \pm 0.06$ & $6.8 \pm 0.08$ & $3.1 \pm 0.3$ & $29 \pm 3.3$ & $68 \pm 10.3$ & $\begin{array}{l}87.6 \pm 10.4 \\
(\mathrm{ND})\end{array}$ & 26.3 & 4.27 & 0.31 \\
\hline$B+X$ & $2.1 \pm 0.8$ & $0.28 \pm 0.05$ & $6.7 \pm 0.16$ & $2.9 \pm 0.3$ & $26 \pm 5.5$ & $71 \pm 10.8$ & $\begin{array}{l}78.1 \pm 5.2 \\
(8.3)\end{array}$ & 26.3 & 3.96 & 0.15 \\
\hline$S+X$ & $1.2 \pm 0.8$ & $0.16 \pm 0.06$ & $7.1 \pm 0.12$ & $2.7 \pm 0.2$ & $33 \pm 2.1$ & $81 \pm 4.9$ & $\begin{array}{l}94.2 \pm 6.8 \\
(\mathrm{ND})\end{array}$ & 18.6 & 2.84 & 0.11 \\
\hline Control & $3.6 \pm 0.5$ & $1.63 \pm 0.29$ & $7.2 \pm 0.14$ & $5.3 \pm 0.2$ & $14 \pm 7.2$ & $45 \pm 15.3$ & $56.6 \pm 9.9$ & 59.7 & 7.11 & 1.18 \\
\hline Guidelines & $\begin{array}{l}<1 \text { not }>3 \\
\text { NTU }\end{array}$ & $\begin{array}{l}\text { SSF: } \\
0.1-0.4\end{array}$ & 7-10.5 & $2-4 \mathrm{ppm}$ & NA & $100 \%$ & $<1 \mu \mathrm{g} / \mathrm{L}$ & $\begin{array}{l}<45 \mathrm{mg} / \\
\mathrm{L}\end{array}$ & $<3 \mathrm{mg} / \mathrm{L}$ & $\begin{array}{l}<0.121 \mathrm{mg} / \\
\mathrm{L}\end{array}$ \\
\hline
\end{tabular}

- Values in bracket means the least effluent MC-LR concentration detected.

- DOC removal is calculated based on the initial lake water condition.

actual cycle study, it showed $<35 \%$ of MC-LR removal (not shown in Fig. 5, Fig. S6).

Extracellular polymeric substance (EPS) ${ }^{16}$ production, which is known to be an important criterion for an initial bacterial attachment to the surface and its subsequent resistance to shear flow which is very important with filtration system perspective [33], was found to be in order: Bacillus sp. (18 mg/g biomass) < Arthrobacter ramosus $(98 \mathrm{mg} / \mathrm{g}$ biomass) $<$ Sphingomonas sp. (138 mg/g biomass). This could explain the fact that Bacillus sp. maintained less integrity in their EPS matrix and could also explain the reason as to why, the filters inoculated with Bacillus sp. (filter $\mathrm{B}$ and $\mathrm{B}+\mathrm{X}$ ) did not contribute well to the biodegradation of MC-LR (less coverage of the green bars indicating biodegradation, Fig. 5). Once a proper bacterial attachment occurred, MC-LR removal increased, as is evident from the MC-LR removal results of filter $A+X$ and $S+X$ (Fig. 5). It can be seen from Fig. S9 that a relatively weaker biofilm was formed for $\mathrm{B}+\mathrm{X}$ as compared to $\mathrm{A}+\mathrm{X}$ and $\mathrm{S}+\mathrm{X}$.

Even the individual MC-LR-degraders (A, B and S) showed an enhancement of $18 \%, 15 \%$ and $21 \%$, respectively in the overall MC-LR removal when compared to the control filter (C). The native bacterial strains (X) also increased the MC-LR removal by $21 \%$. Likewise, McDowall et al. (2009) [34] reported that biodegradation played a pivotal role in the removal of a secondary cyanobacterial metabolite: geosmin, by an additional 38\%. Interestingly, co-cultured Bacillus sp.-native bacterial strains filter $(\mathrm{B}+\mathrm{X})$, showed no improvement ( $0-0.5 \%$ difference) when compared to filter X, rightly justifying the effect of lower EPS formation by Bacillus sp. which suggested the weak attachment of Bacillus sp. to the sand surface.

It is interesting to observe that the backwashing event (end of the 4th cycle) might have retained the more resistant and better-attached bacteria in $\mathrm{S}+\mathrm{X}$ and $\mathrm{A}+\mathrm{X}$ and showed fast growth in the next cycle (5th) to allow complete MC-LR removal in the last three cycles (see cycles 6-8 in Fig. 5). However, a breakthrough of MC-LR was observed after the 8th cycle in both these filters (not shown here). Also, the ability of MC-LR-degraders to survive in conjugation with the native bacterial strains (X) can be a contributing factor enhancing the biodegradation. Likewise, filter $\mathrm{B}+\mathrm{X}$ showed $10 \%$ and $16 \%$ less MC-LR biodegradation potential as compared to $\mathrm{A}+\mathrm{X}$ and $\mathrm{S}+\mathrm{X}$,

\footnotetext{
${ }^{16}$ Determined using ethanol precipitation method by sampling biofilm formed over the
} top layer of sand-filter during bioprofiling step respectively, and an early breakdown (after 5th cycle) as compared to the consistent performance of $\mathrm{A}+\mathrm{X}$ and $\mathrm{S}+\mathrm{X}$ where breakdown phenomenon occurred after the 8th cycle. The initial breakthrough of MC-LR in filter A $+\mathrm{X}$ and $\mathrm{S}+\mathrm{X}$ (cycle 1, post-biofilm establishment) shows evidence of acclimation period followed by a consistent decrease in MC-LR concentration in the filtered sample which suggested that the majority of degradation had been achieved through the biological process [15]. However, the acclimation period in this study was comparatively lower ( 1 cycle or 7 days) than other studies $[16,18]$. Ho et al. (2006) [14] also observed a very short initial breakthrough period of just 4 days. Many studies also attribute the presence of more advanced bacterial community in a biofilm for a quick acclimation of MCs which reduces the initial breakthrough period and advanced the biodegradation period, once the bacteria adhered well to the surface $[36,37]$.

At the end of each cycle, the filtered samples were assayed for toxicity. The toxicity of the sample was determined by the percentage equivalent of DMSO (tested as a surrogate toxic chemical to MC-LR) for the same absorbance values offered by MC-LR which was eventually related to the cell viability of the bioindicator. The established relationship between the absorbance values vs. equivalent DMSO and MC-LR is shown in the supplementary section (Figs. S7 and S8). ${ }^{17}$ Maximum average equivalent DMSO value of $16 \%$ and $12 \%$ were reported for sample filtered from control filter $\mathrm{C}$ and filter B, respectively, indicating toxic effects to human cells. MC-LR-degraders co-cultured with $\mathrm{X}$ showed comparatively lower DMSO equivalent value than the individual strain counterparts. The least toxic sample was reported for filter $S+X(0.19 \%$ eq. DMSO) followed by A + X (0.6\% eq. DMSO). Many researchers have reported the toxic effects of DMSO on human cells and other species. At $1 \%(\mathrm{v} / \mathrm{v}), 0.6 \%(\mathrm{v} / \mathrm{v}), 0.5 \%-2 \%(\mathrm{v} / \mathrm{v})$ of DMSO, an effect on the neuronal cell line of rats, vascular endothelial and platelet cells on humans, and suppressing action on the expression of many pro-inflammatory cytokines/chemokines, respectively was reported [38-40]. Considering the above statement, filtered samples from filter inoculated with $\mathrm{S}+\mathrm{X}$ and $\mathrm{A}+\mathrm{X}$ can be assumed safer than other filters. Also, the degraded by-products as obtained from the mass spectra analysis showed $\mathrm{m} / \mathrm{z}$ values of $155,213,268,315,375$, 553, 862.5 (Fig. S10). These seven major by-products were similar to

\footnotetext{
${ }^{17}$ However, this experiment is not the best way to determine the toxicity as the margin

for absorbance values are very small sometimes.
} 
the degraded by-products as reported in our previous research work, where MC-LR removal was studied using moving bed biofilm reactors (MBBR) [41]. It may be because same MC-LR-degraders were bioaugmented individually in separate MBBR reactor for the development of the biofilm over the K1 Kaldness adsorbents. In the previous study, the proposed mechanism of MC-LR degradation from the obtained by-products with these $m / z$ values directed the possibility towards a toxic-free transformation mechanism (devoid of ADDA peptide) $[41,42]$. However, as mentioned in Section 2.5.3 that the toxicity assay needs further validation using ELISA assay kits which are specific tools for measuring toxicity.

\subsection{Bio-profiling of column filters}

To quantify cell biomass and cell viability for the entire depth of the filter column, bio-profiling of each filter was performed as discussed in Section 2.6. Fig. 6(A) and (B) shows the cell biomass bio-profile whereas Fig. 6(C) and (D) shows cell viability bio-profile of each filter. Most active bacteria were found within the top $15 \mathrm{~cm}$ of the filter column. Control filter (C) showed a linear profile as compared to other filters, indicating less to no bioactivity throughout the column depth. Filter S + X showed highest cell biomass and almost constant bio-profile for cell viability up to $15 \mathrm{~cm}$ depth (Fig. 6 (D)). This could be the reason for filter $\mathrm{S}+\mathrm{X}$ accounting for the highest MC-LR degradation among all filters. This may be linked to an effective attachment (not sheared away easily) of the bacterial strains $(S+X)$ over the sand particle which can also be seen from the SEM images (Fig. S9: supplementary file). Ho et al. (2006) [14] too observed high biomass density at the filter top where they identified the same bacterial species, i.e., 'Sphingomonas' (91\% similarity to Sphingomonas sp. CM-3962) as used in filter S + X. As discussed by Ho et al. (2006) [14], the biomass at the top portion of the column was around 6-8 times higher than the bottom and had higher enzyme activity ( 2 times using peptidase assay) than the latter. In the present study, MTT assay was used as a marker of viable cells to measure the enzymatic activity that showed similar behavior (2.5 times higher bioactivity at the top than at the bottom). In general, Sphingomonas sp. (filter S or S $\mathrm{X}$ ) showed the higher bioactivity and cell biomass (Fig. 6) as compared to other MC-LR-degraders, i.e., Bacillus sp. and Arthrobacter ramosus, which could be related to the high MC-LR degradation [14].

Known MC-LR-degrader species in the form of Arthrobacter, Bacillus and Sphingomonas was co-cultured with the native bacterial strains residing over the filtration unit of a DWTP. It may be inferred that the source water in DWTP (St. Lawrence River) consists of these microorganisms (native: $\mathrm{X}$ ) that had built up over the years through the continuous influent discharge in the filtration unit, showing attached growth, eventually becoming potent in degrading microcystin. From our previous study, their ability to degrade the MC-LR was slower under suspended growth method $(19.4 \mu \mathrm{g} / \mathrm{L} / \mathrm{d})$ as compared to the attached growth degradation rate (2-log increase in the present study). However, it may also be noted that the former had $6 \times 10^{6}$ cells $/ \mathrm{mL}$ of initial inoculum concentration (IIC) and latter had IIC of $6 \times 10^{8}$ cells $/ \mathrm{mL}$. Nevertheless, owing to the retention time (15-45 $\mathrm{min}$ ) of the filtration unit of a typical DWTP, the best-evaluated filter in the current study (retention time of $64 \mathrm{~min}$ ), i.e., $S+\mathrm{X}$, may not be promising to remove MCs below WHO guidelines $(1 \mu \mathrm{g} / \mathrm{L}$ for human and $0.3 \mu \mathrm{g} / \mathrm{L}$ for children) within $25 \mathrm{~min}$. Table 3 shows the overall evaluation of filters used in this study and it can be observed that $\mathrm{S}+\mathrm{X}$ met other drinking
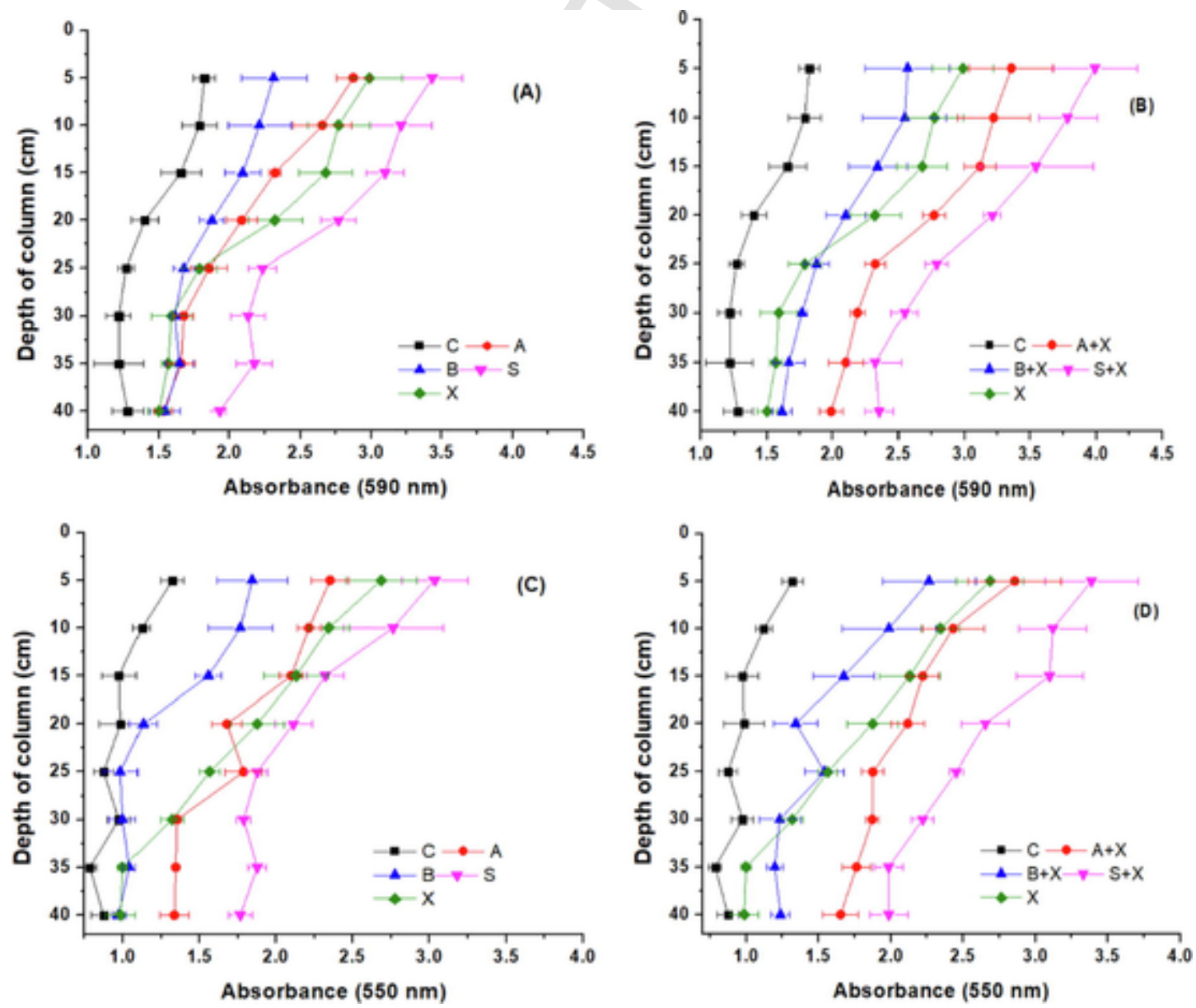

Fig. 6. A) and B): Cell biomass bioprofile of the filters; C) and D) Cell viability bioprofile of the filters. 
water quality parameters such as, turbidity, total coliforms, nitrate, nitrite and ammonia removal. Table 4 shows some filtration column studies that were performed for the removal of microcystin. The bacterial genera: Sphingomonas was found to be a potential MC degrader for the active biological filter studies $[14,16]$.

Also, in past, the referred native bacterial community (dominant) of genera Chryseobacterium and Pseudomonas, has also shown capability in removing other secondary cyanobacterial metabolites including geosmin and 2-methylisoborneol (MIB) [43-45]. Some studies have shown promising biological treatment of other cyanotoxins apart from MCs, such as cylindrospermopsin and nodularin via bacterial of genera used in this study viz. Arthrobacter, Bacillus. and Sphingomonas [46-48]. For the first time, the potential of these three listed bacteria (non-pathogenic to human as well) were studied in conjugation with the identified and dominant native bacteria residing in the filtration unit of a DWTP. Hence, in future, proper seeding method of these MC-LR degraders (also capable of handling other cyanotoxins) can be performed to tackle the toxicity posed by various cyanotoxins. DWTP operators may also utilize the backwashing facility to recirculate the MC-LR-degraders as a seeding technique to tackle the MCs removal challenge occurring for a shorter period of the year [33].

However, some research gaps, such as achieving lower retention time or empty bed contact time (EBCT), can be overcome by decreasing the IIC that will enable higher flow rate (higher penetration of fluid because of lower cell biomass growth) and will possibly help in MC-LR removal within the retention period of $15-25 \mathrm{~min}$. Other common microcystin congeners such as Microcystin-RR needs to be evaluated too as they have different adsorption characteristics [49]. Also, exploring more MC-LR-degraders along with the other native bacterial strains isolated from the filtration unit of other DWTP can further help the plant operators to accomplish the degree of MC treatment required.

\section{Conclusion}

Microcystin (MC)-degraders of genera, Sphingomonas (S) and Arthrobacter (A), inoculated with the already present bacterial strains in the filtration unit ( $\mathrm{X}=$ Pseudomonas fragi and Chryseobacterium sp.) of the drinking water treatment plant (DWTP), enhanced removal of MC-LR. Bacterial co-culturing helped in improving MC-LR removal by almost $17 \%$ (to $94 \%$ in S + X case). The presence of MC-LR in the filtration system showed no negative effect on the removal/treatment of other drinking water quality parameters such as ammonia, nitrate, nitrite, coliform removal, among others. Toxicity assessment determined in terms of equivalent DMSO concentration showed less to no toxicity (reduced from $9 \%$ to $0.19 \%$ and $0.6 \%$ for $\mathrm{S}+\mathrm{X}$ and $\mathrm{A}+\mathrm{X}$, respectively) to human cells when MC-LR-degraders was co-cultured with the native bacterial strains of the filtration unit of a DWTP. Such a treatment method can also promise to assure safe drinking water to the small communities in the form of biosand filters, especially where source water is affected by cyanobacterial bloom secreting MCs.

Future gap and research implications:

a) Filter $\mathrm{A}+\mathrm{X}$ and $\mathrm{S}+\mathrm{X}$ showed promise in MC-LR removal for a few cycles. However, the toxin breakthrough after backwashing was evident from the analysis and hence future experiments need to be performed to understand the long-term stability of the filter media (for e.g.: modification in the sand media)

b) An experiment related to the optimization of the bacterial inoculum can be performed for an effective biofilm formation over the sand media.

c) Also, an adsorption isotherm needs to be developed for the sand media with and without the inoculated bacterial cells to understand the kinetics of the MC-LR removal at various concentrations.

d) Native bacteria found in DWTPs can be different and hence simple co-culturing MC-degraders to accelerate MCs degradation cannot be extrapolated.

Table 4

Various studies reported for the sand filter for the microcystin removal.

\begin{tabular}{|c|c|c|c|c|c|c|c|}
\hline Filter type & Filter specification & $\begin{array}{l}\text { Cyanotoxin } \\
\text { studied }\end{array}$ & $\begin{array}{l}\text { Degradation/removal } \\
\%\end{array}$ & $\begin{array}{l}\text { Initial } \\
\text { toxin }\end{array}$ & Degradation period & Bacteria inoculated & References \\
\hline $\begin{array}{l}\text { Biologically } \\
\text { active sand } \\
\text { filter }\end{array}$ & $\begin{array}{l}0.5 \mathrm{~mL} / \mathrm{min} \text {, sand size: } 0.5 \mathrm{~mm} \text {, } \\
\text { height }=1 \mathrm{~m} \text {; Diameter } 3.5 \mathrm{~cm}^{*}\end{array}$ & $\begin{array}{l}{\left[\mathrm{Dha}^{7}\right]} \\
\text { microcystin- } \\
\text { LR }\end{array}$ & $100 \%$ & $5000 \mu \mathrm{g} / 1$ & $\begin{array}{l}7 \text { d EBCT: not } \\
\text { mentioned }\end{array}$ & $\begin{array}{l}\text { Novosphingobium sp. } \\
\text { KKU15 (bacterial } \\
\text { concentration of } \\
1.6 \times 10^{7} \mathrm{CFU} / \mathrm{cm}^{3} \text { of } \\
\text { sand) }\end{array}$ & {$[50]$} \\
\hline $\begin{array}{l}\text { Slow sand } \\
\text { and bank } \\
\text { filtration }\end{array}$ & $\begin{array}{l}0.8 \mathrm{~m}-1.3 \mathrm{~m} \text { sand height, } 0.6 \mathrm{~m} / \\
\mathrm{d}-2.4 \mathrm{~m} / \mathrm{d} \text { (filter rate) }\end{array}$ & Microcystins & $62 \%-78 \%$ & $6-10 \mu \mathrm{g} / 1$ & $8 h-24 h *$ & NA & {$[51]$} \\
\hline $\begin{array}{l}\text { Biologically } \\
\text { active sand } \\
\text { filter }\end{array}$ & $\begin{array}{l}\text { height } 30 \mathrm{~cm} \text {, internal diameter } \\
2.5 \mathrm{~cm} \text {; Flow rate: } 0.3-1.2 \mathrm{~m} / \mathrm{h}\end{array}$ & $\begin{array}{l}\text { MC-LR and } \\
\text { MC-LA }\end{array}$ & $>95 \%$ & $\begin{array}{l}20-25 \mu \mathrm{g} / \\
1\end{array}$ & (EBCT: $7.5-30 \mathrm{~min}$ ) & $\begin{array}{l}\text { Sphingopyxis sp. C1 (NCBI } \\
\text { accession number } \\
\text { AB161685); } \\
\text { Sphingomonas sp. } \\
\text { ACM-3962 }\end{array}$ & [14] \\
\hline $\begin{array}{l}\text { Biologically } \\
\text { active slow } \\
\text { sand filters }\end{array}$ & $\begin{array}{l}0.5 \mathrm{~m} \text { sand and } 0.3 \mathrm{~m} \text { water; PVC } \\
\text { piping, } 100 \mathrm{~mm} \text { in diameter; sand } \\
\text { size: } 0.20-0.40 \mathrm{~mm}\end{array}$ & MC-LR & $>75 \%$ & $50 \mu \mathrm{g} / 1$ & 1d; EBCT: NA & $\begin{array}{l}\text { Sphingomonas } \mathrm{sp} \\
\left(5 \times 10^{8} \text { cells }(\mathrm{in} \text { a }\right. \\
\text { volume of } 10 \mathrm{~mL})\end{array}$ & [16] \\
\hline $\begin{array}{l}\text { Biological } \\
\text { Sand Filters }\end{array}$ & $\begin{array}{l}\text { length of } 30 \mathrm{~cm} \text {, inner diameter } \\
\text { of } 2.5 \mathrm{~cm} \text { at a bed height of } \\
15 \mathrm{~cm} \text {; flow rate: } 0.6 \mathrm{~m} / \mathrm{h}\end{array}$ & MC-LR & $100 \%$ & $3-20 \mu \mathrm{g} / 1$ & $4 \mathrm{~d} ; 15 \mathrm{~min} \mathrm{EBCT}$ & $\begin{array}{l}\text { Sphingopyxis sp. C-1 } \\
\text { (NCBI accession number } \\
\text { AB161685) }\end{array}$ & [15] \\
\hline $\begin{array}{l}\text { Household } \\
\text { slow Sand } \\
\text { filter }\end{array}$ & $\begin{array}{l}\text { Bed depth: } 55 \mathrm{~cm} \text {; sand size: } \\
0.153 \mathrm{~mm} \text {, diameter: } 250 \mathrm{~mm}\end{array}$ & MC-LR & $>75 \%$ & $5.5 \mu \mathrm{g} / 1$ & $\begin{array}{l}\text { Intermittent flow } \\
\left(2.95 \mathrm{~m}^{3} \mathrm{~m}^{-2} / \mathrm{d}\right) \text { and } \\
\text { continuous flow } \\
\left(1.22 \mathrm{~m}^{3} \mathrm{~m}^{-2} / \mathrm{d}\right) \text {; } \\
\text { EBCT: } 6 \mathrm{~h}^{*}\end{array}$ & NA & {$[52]$} \\
\hline $\begin{array}{l}\text { Biosand } \\
\text { filter }\end{array}$ & $\begin{array}{l}\text { Length of } 0.65 \mathrm{~m} \text { sand; } 25 \mathrm{~mm} \\
\text { diameter; bed height (sand) of } \\
0.49 \mathrm{~m} \text {; flow rate: } 0.15 \mathrm{~m} / \mathrm{h}\end{array}$ & MC-LR & $94.2 \%{ }^{\#}$ & $50 \mu \mathrm{g} / 1$ & $\begin{array}{l}8 \text { cycle study ( } 56 \text { days); } \\
\text { Max EBCT: } 70 \text { min }\end{array}$ & Sphingomonas sp. & This study \\
\hline
\end{tabular}

Values calculated based on the information available in the article; \#Breakthrough of MC-LR occurred after backwashing and after 8-week study 


\section{Uncited reference}

[35].

\section{Declaration of Competing Interest}

The authors declare that they have no known competing financial interests or personal relationships that could have appeared to influence the work reported in this paper.

\section{Acknowledgments}

The authors are sincerely thankful to the Natural Sciences and Engineering Research (Discovery Grant 23451), Genome Québec, Genome Canada) and ATRAPP (Algal blooms, treatment, risk assessment, prediction and prevention) for financial support. Special thanks to Dana Simon for coordinating the sample receipt and analysis. Authors would also like to thank the team for constant support and timely suggestions. We would like to thank Genome Quebec for timely sequencing for the bacterial identification. The views or opinions expressed in this article is exclusively those of the authors.

\section{Appendix A. Supplementary data}

Supplementary data to this article can be found online at https://doi. org/10.1016/j.cej.2019.123090.

\section{References}

[1] M. Welker, C. Steinberg, Rates of humic substance photosensitized degradation of microcystin-LR in natural waters, Environ. Sci. Technol. 34 (16) (2000) 3415-3419, doi:10.1021/es991274t.

[2] World Health Organisation. Public Health and the Environment. WHO; Geneva: 2009. Guidelines for drinking water quality policies and procedures used in updating the WHO Guidelines for Drinking Water Quality.

[3] A. Ramani, K. Rein, K.G. Shetty, K. Jayachandran, Microbial degradation of microcystin in Florida's freshwaters, Biodegradation 23 (1) (2011) 35-45, doi:10.1007/s10532-011-9484-y.

[4] J. Chang, Z.-L. Chen, Z. Wang, J. Kang, Q. Chen, L. Yuan, J.-M. Shen, Oxidation of microcystin-LR in water by ozone combined with UV radiation: the removal and degradation pathway, Chem. Eng. J. 276 (2015) 97-105, doi:10.1016/ j.cej.2015.04.070.

[5] F. Sun, H.-Y. Pei, W.-R. Hu, C.-X. Ma, The lysis of Microcystis aeruginosa in Al$\mathrm{Cl} 3$ coagulation and sedimentation processes, Chem. Eng. J. 193-194 (2012) 196-202, doi:10.1016/j.cej.2012.04.043.

[6] J.L. Clancy, T.M. Hargy, Waterborne: Drinking Water (ch. 11), in: R. Fayer, L. Xiao (Eds.), Cryptosporidium and Cryptosporidiosis, 2nd ed., CRC Press, Boca Raton, 2008.

[7] J. Lee, H.W. Walker, Mechanisms and factors influencing the removal of microcystin-LR by ultrafiltration membranes, J. Membr. Sci. 320 (2008) 240-247.

[8] J. Sun, L. Bu, L. Deng, Z. Shi, S. Zhou, Removal of Microcystis aeruginosa by UV/chlorine process: inactivation mechanism and microcystins degradation, Chem. Eng. J. 349 (2018) 408-415, doi:10.1016/j.cej.2018.05.116.

[9] Y. Zhang, Y. Shao, N. Gao, W. Chu, Z. Sun, Removal of microcystin-LR by free chlorine: identify of transformation products and disinfection by-products formation, Chem. Eng. J. 287 (2016) 189-195, doi:10.1016/j.cej.2015.10.111.
[10] W. Zong, F. Sun, H. Pei, W. Hu, R. Pei, Microcystin-associated disinfection by-products: the real and non-negligible risk to drinking water subject to chlorination, Chem. Eng. J. 279 (2015) 498-506, doi:10.1016/j.cej.2015.05.048.

[11] D.G. Bourne, G.J. Jones, R.L. Blakeley, A. Jones, A.P. Negri, P. Riddles, Enzymatic pathway for the bacterial degradation of the cyanobacterial cyclic peptide toxin microcystin LR, Appl. Environ. Microbiol. 62 (11) (1996) 4086-4094.

[12] I. Sovadinova, P. Babica, O. Adamovský, A. Alpatová, V. Tarabara, B.L. Upham, L. Bláha, Chlorination and ozonation reduce microcystin content and tumour promoting activity of complex cyanobacterial extract, Adv. Oceanogr. Limnol. 8 (1) (2017), doi:10.4081/aiol.2017.6342.

[13] T. Somdee, J. Wibuloutai, T. Somdee, A. Somdee, Biodegradation of the cyanobacterial hepatotoxin [Dha7] microcystin-LR within a biologically active sand filter, Water Sci. Technol. Water Supply 14 (4) (2014) 672-680, doi:10.2166/ws.2014.024.

[14] L. Ho, T. Meyn, A. Keegan, D. Hoefel, J. Brookes, C.P. Saint, G. Newcombe, Bacterial degradation of microcystin toxins within a biologically active sand filter, Water Res. 40 (4) (2006) 768-774, doi:10.1016/j.watres.2005.12.009.

[15] L. Ho, D. Hoefel, C.P. Saint, G. Newcombe, Degradation of microcystin-LR through biological sand filters, Practice Period. Hazard., Toxic, Radioact. Waste Manage. 11 (3) (2007) 191-196, doi:10.1061/(asce)1090-025x(2007) 11:3(191).

[16] D.G. Bourne, R.L. Blakeley, P. Riddles, G.J. Jones, Biodegradation of the cyanobacterial toxin microcystin LR in natural water and biologically active slow sand filters, Water Res. 40 (6) (2006) 1294-1302, doi:10.1016/ j.watres.2006.01.022.

[17] Y. Phujomjai, T. Somdee http://www.jolst.net/index.php?m = content\& $\mathrm{c}=$ index\&a $=$ show\&catid $=34 \& \mathrm{id}=66,2013$, Journal of Life Sciences and Technologies, 220-222. doi: 10.12720/jolst.1.4.220-222.

[18] F. Yang, I.Y. Massey, J. Guo, S. Yang, Y. Pu, W. Zeng, H. Tan, Microcystin-LR degradation utilizing a novel effective indigenous bacterial community YFMCD1 from Lake Taihu, J. Toxicol. Environ. Health, Part A 81 (7) (2018) 184-193.

[19] F. Yang, J. Guo, F. Huang, I. Massey, R. Huang, Y. Li, C. Wen, P. Ding, W. Zeng, G. Liang, Removal of microcystin-LR by a novel native effective bacterial community designated as YFMCD4 isolated from Lake Taihu, Toxins 10 (9) (2018).

[20] I.Y. Massey, X. Zhang, F. Yang, Importance of bacterial biodegradation and detoxification processes of microcystins for environmental health, J. Toxicol. Environ. Health, Part B 21 (6-8) (2018) 357-369.

[21] P. Kumar, K. Hegde, S.K. Brar, M. Cledon, A. Kermanshahi-pour, A. Roy-Lachapelle, R. Galvez-Cloutier, Biodegradation of microcystin-LR using acclimatized bacteria isolated from different units of the drinking water treatment plant, Environ. Pollut. 242 (2018) 407-416, doi:10.1016/j.envpol.2018.07.008.

[22] S. Chusri, K. Sompetch, S. Mukdee, S. Jansrisewangwong, T. Srichai, K. Maneenoon, S.P. Voravuthikunchai, Inhibition of Staphylococcus epidermidis biofilm formation by traditional thai herbal recipes used for wound treatment, Evid.-Based Complem. Altern. Med. 2012 (2012) 1-8, doi:10.1155/2012/ 159797.

[23] M.M. Bradford, A rapid and sensitive method for the quantitation of microgram quantities of protein utilizing the principle of protein-dye binding, Anal. Biochem. 72 (1-2) (1976) 248-254, doi:10.1016/0003-2697(76)90527-3.

[24] APHA, AWWA, WPCF. 1998. Standard methods for the examination of water and wastewater, 19th ed., Washington, D.C.

[25] M. Asrafuzzaman, A.N.M. Fakhruddin, M.A. Hossain, Reduction of turbidity of water using locally available natural coagulants, ISRN Microbiol. 2011 (2011) 1-6, doi:10.5402/2011/632189.

[26] M. Naghdi, M. Cledon, S.K. Brar, A.A. Ramirez, Nitrification of vegetable waste using nitrifying bacteria, Ecol. Eng. (2017), doi:10.1016/j.ecoleng.2017.07.003

[27] D.O. Mountfort, P. Holland, J. Sprosen, Method for detecting classes of microcystins by combination of protein phosphatase inhibition assay and ELISA: comparison with LC-MS, Toxicon 45 (2) (2005) 199-206, doi:10.1016/ j.toxicon.2004.10.008.

[28] P.B. Fayad, A. Roy-Lachapelle, S.V. Duy, M. Prévost, S. Sauvé, On-line solid-phase extraction coupled to liquid chromatography tandem mass spectrometry for the analysis of cyanotoxins in algal blooms, Toxicon 108 (2015) 167-175, doi:10.1016/j.toxicon.2015.10.010. 
[29] D.L. Balkwill, J.K. Fredrickson, M.F. Romine, Sphingomonas and related genera, Prokaryotes (2006) 605-629, doi:10.1007/0-387-30747-8_23.

[30] L. Eleuterio, J.R. Batista, Biodegradation studies and sequencing of microcystin-LR degrading bacteria isolated from a drinking water biofilter and a fresh water lake, Toxicon 55 (8) (2010) 1434-1442, doi:10.1016/ j.toxicon.2010.02.020.

[31] J. Lu, T. Zhang, J. Ma, Z. Chen, Evaluation of disinfection by-products formation during chlorination and chloramination of dissolved natural organic matter fractions isolated from a filtered river water, J. Hazard. Mater. 162 (1) (2009) 140-145, doi:10.1016/j.jhazmat.2008.05.058.

[32] B. Li, Y. Qiu, C. Zhang, L. Chen, H. Shi, Understanding biofilm diffusion profiles and microbial activities to optimize integrated fixed-film activated sludge process, Chem. Eng. J. 302 (2016) 269-277, doi:10.1016/j.cej.2016.05.048.

[33] P.G. Jayathilake, S. Jana, S. Rushton, D. Swailes, B. Bridgens, T. Curtis, J. Chen, Extracellular polymeric substance production and aggregated bacteria colonization influence the competition of microbes in biofilms, Front. Microbiol. 8 (2017), doi:10.3389/fmicb.2017.01865.

[34] B. McDowall, D. Hoefel, G. Newcombe, C.P. Saint, L. Ho, Enhancing the biofiltration of geosmin by seeding sand filter columns with a consortium of geosmin-degrading bacteria, Water Res. 43 (2) (2009) 433-440, doi:10.1016/ j.watres.2008.10.044.

[35] M.J. Miller, H.J. Fallowfield, Degradation of cyanobacterial hepatotoxins in batch experiments, Water Sci. Technol. 43 (12) (2001) 229-232.

[36] T. Holst, N.O.G. Jørgensen, C. Jørgensen, A. Johansen, Degradation of microcystin in sediments at oxic and anoxic, denitrifying conditions, Water Res. 37 (19) (2003) 4748-4760, doi:10.1016/s0043-1354(03)00413-5.

[37] K. Christoffersen, S. Lyck, A. Winding, Microbial activity and bacterial community structure during degradation of microcystins, Aquat. Microb. Ecol. 27 (2002) 125-136, doi:10.3354/ame027125.

[38] J. Galvao, B. Davis, M. Tilley, E. Normando, M.R. Duchen, M.F. Cordeiro, Unexpected low-dose toxicity of the universal solvent DMSO, FASEB J. 28 (3) (2014) 1317-1330, doi:10.1096/fj.13-235440.

[39] X. Yi, M. Liu, Q. Luo, H. Zhuo, H. Cao, J. Wang, Y. Han, Toxic effects of dimethyl sulfoxide on red blood cells, platelets, and vascular endothelial cells in vitro, FEBS Open Bio 7 (4) (2017) 485-494, doi:10.1002/2211-5463.12193.

[40] P. Proost, I. Elisia, H. Nakamura, V. Lam, E. Hofs, R. Cederberg, G. Krystal, DMSO represses inflammatory cytokine production from human blood cells and reduces autoimmune arthritis, PLoS One 11 (3) (2016), doi:10.1371/ journal.pone.0152538 e0152538.
[41] P. Kumar, K. Hegde, S.K. Brar, M. Cledon, A. Kermanshahi-pour, A. Roy-Lachapelle, R. Galvez-Cloutier, Novel fluidized-bed biofilm reactor for concomitant removal of microcystin-LR and organics, Chem. Eng. J. 359 (2019) 99-111, doi:10.1016/j.cej.2018.11.119.

[42] K.-I. Harada, S. Imanishi, H. Kato, M. Mizuno, E. Ito, K. Tsuji, Isolation of Adda from microcystin-LR by microbial degradation, Toxicon 44 (1) (2004) 107-109, doi:10.1016/j.toxicon.2004.04.003.

[43] K. Egashira, K. Ito, Y. Yoshiy, Removal of musty odor compound in drinking water by biological filter, Water Sci. Technol. 25 (2) (1992) 307-314, doi:10.2166/wst.1992.0066.

[44] R.W. Eaton, P. Sandusky, Biotransformations of (+/-)-geosmin by terpene-degrading bacteria, Biodegradation 21 (1) (2009) 71-79, doi:10.1007/ s10532-009-9282-y.

[45] B. Zhou, R. Yuan, C. Shi, L. Yu, J. Gu, C. Zhang, Biodegradation of geosmin in drinking water by novel bacteria isolated from biologically active carbon, J. Environ. Sci. (China) 23 (5) (2011) 816-823.

[46] H. Kato, S.Y. Imanishi, K. Tsuji, K.-I. Harada, Microbial degradation of cyanobacterial cyclic peptides, Water Res. 41 (8) (2007) 1754-1762, doi:10.1016/j.watres.2007.01.003.

[47] L.A. Lawton, A. Welgamage, P.M. Manage, C. Edwards, Novel bacterial strains for the removal of microcystins from drinking water, Water Sci. Technol. 63 (6) (2011) 1137-1142, doi:10.2166/wst.2011.352.

[48] Z.A. Mohamed, S.A. Alamri, Biodegradation of cylindrospermopsin toxin by microcystin-degrading bacteria isolated from cyanobacterial blooms, Toxicon 60 (8) (2012) 1390-1395, doi:10.1016/j.toxicon.2012.10.004.

[49] M. Sathishkumar, S. Pavagadhi, K. Vijayaraghavan, R. Balasubramanian, S.L. Ong, Concomitant uptake of microcystin-LR and -RR by peat under various environmental conditions, Chem. Eng. J. 172 (2-3) (2011) 754-762, doi:10.1016/ j.cej.2011.06.058

[50] H. Wang, L. Ho, D.M. Lewis, J.D. Brookes, G. Newcombe, Discriminating and assessing adsorption and biodegradation removal mechanisms during granular activated carbon filtration of microcystin toxins, Water Res. 41 (18) (2007) 4262-4270, doi:10.1016/j.watres.2007.05.057.

[51] G. Grützmacher, G. Böttcher, I. Chorus, H. Bartel, Removal of microcystins by slow sand filtration, Environ. Toxicol. 17 (4) (2002) 386-394, doi:10.1002/ tox.10062.

[52] U.C. Terin, L.P. Sabogal-Paz, Microcystis aeruginosa and microcystin-LR removal by household slow sand filters operating in continuous and intermittent flows, Water Res. 150 (2019) 29-39, doi:10.1016/j.watres.2018.11.055 